\title{
Review \\ Selective Targeting of Epigenetic Readers and Histone Deacetylases in Autoimmune and Inflammatory Diseases: Recent Advances and Future Perspectives
}

\author{
Mohammed Ghiboub ${ }^{1,2,+}\left(\mathbb{D}\right.$, Ahmed M. I. Elfiky ${ }^{1,2,+}$, Menno P. J. de Winther ${ }^{3,4} \mathbb{D}$, Nicola R. Harker ${ }^{2}$, \\ David F. Tough ${ }^{2} \mathbb{D}$ and Wouter J. de Jonge $1,5, * \mathbb{C}$ \\ 1 Tytgat Institute for Liver and Intestinal Research, Amsterdam Gastroenterology Endocrinology Metabolism \\ Research Institute, Amsterdam University Medical Centers, University of Amsterdam, 1105 BK Amsterdam, \\ The Netherlands; m.ghiboub@amsterdamumc.nl (M.G.); a.m.elfiky@amsterdamumc.nl (A.M.I.E.) \\ 2 Adaptive Immunity Research Unit, Medicines Research Centre, GlaxoSmithKline, Stevenage SG1 2NY, UK; \\ nicola.r.harker@gsk.com (N.R.H.); david.f.tough@gsk.com (D.F.T.) \\ 3 Department of Medical Biochemistry, Amsterdam University Medical Centers, University of Amsterdam, \\ 1105 AZ Amsterdam, The Netherlands; m.dewinther@amsterdamumc.nl \\ 4 Department of Medicine, Institute for Cardiovascular Prevention (IPEK), 80336 Munich, Germany \\ 5 Department of Surgery, University of Bonn, 53127 Bonn, Germany \\ * Correspondence: w.j.dejonge@amsterdamumc.nl; Tel.: +31-20-566-8163 \\ + These authors contributed equally to this work.
}

check for updates

Citation: Ghiboub, M.; Elfiky, A.M.I.; de Winther, M.P.J.; Harker, N.R.; Tough, D.F.; de Jonge, W.J. Selective Targeting of Epigenetic Readers and Histone Deacetylases in Autoimmune and Inflammatory Diseases: Recent Advances and Future Perspectives. J. Pers. Med. 2021, 11, 336. https:// doi.org/10.3390/jpm11050336

Academic Editor: Roberto Díaz Peña

Received: 30 March 2021

Accepted: 19 April 2021

Published: 23 April 2021

Publisher's Note: MDPI stays neutral with regard to jurisdictional claims in published maps and institutional affiliations.

Copyright: (c) 2021 by the authors. Licensee MDPI, Basel, Switzerland. This article is an open access article distributed under the terms and conditions of the Creative Commons Attribution (CC BY) license (https:// creativecommons.org/licenses/by/ $4.0 /)$.
Abstract: Histone deacetylases (HDACs) and bromodomain-containing proteins (BCPs) play a key role in chromatin remodeling. Based on their ability to regulate inducible gene expression in the context of inflammation and cancer, HDACs and BCPs have been the focus of drug discovery efforts, and numerous small-molecule inhibitors have been developed. However, dose-limiting toxicities of the first generation of inhibitors, which typically target multiple HDACs or BCPs, have limited translation to the clinic. Over the last decade, an increasing effort has been dedicated to designing class-, isoform-, or domain-specific HDAC or BCP inhibitors, as well as developing strategies for cell-specific targeted drug delivery. Selective inhibition of the epigenetic modulators is helping to elucidate the functions of individual epigenetic proteins and has the potential to yield better and safer therapeutic strategies. In accordance with this idea, several in vitro and in vivo studies have reported the ability of more selective HDAC/BCP inhibitors to recapitulate the beneficial effects of pan-inhibitors with less unwanted adverse events. In this review, we summarize the most recent advances with these strategies, discussing advantages and limitations of these approaches as well as some therapeutic perspectives, focusing on autoimmune and inflammatory diseases.

Keywords: epigenetics; histone deacetylases; bromodomain; inhibitor; esterase sensitive motif; autoimmune and inflammatory diseases

\section{Introduction}

The human immune system requires complex mechanisms of regulation to avoid the induction of inappropriate responses, and defects in this regulation result in inflammatory and autoimmune diseases [1,2]. Epigenetics refers to mechanisms that modify cellular and organismal phenotypes without altering the DNA sequence and are linked to modified patterns of gene expression [3]. The critical role of epigenetic mechanisms in regulating gene expression in the immune system is well established, and the dysregulation of epigenetic control contributes to the development of a variety of human diseases [4,5]. Three main mechanisms are commonly ascribed to contribute to epigenetic regulation: (1) RNA interference via noncoding RNAs that modify mRNA translation; (2) DNA methylation, and (3) histone post-translational modification [6-8]. All of them can modify the structure 
of chromatin - the ordered structure of DNA and histones-and ultimately the accessibility of DNA to the transcriptional machinery [6-8].

Histones are modified in a dynamic way by enzymes that add or erase a wide range of post-translational modifications, including acetyl or methyl groups, to a variety of different amino acids [9]. These modifications can directly affect the interaction between histones and DNA - for example, by changing the charge of the histone-and can also serve as recognition marks for epigenetic "reader" proteins; both of these processes alter DNA accessibility to transcription factors (TFs) (Figure 1) [9]. Enzymes that add or remove histone marks have been referred to as epigenetic "writers" or "erasers", respectively [9]. Among the wide diversity of possible epigenetic targets, this review will focus on histone deacetylase (HDAC) enzymes and bromodomain (BD)-containing proteins (BCPs), remodelers of histone tails, which play a central role in regulating inducible gene expression involved in immune response [10,11]. HDAC enzymes are examples of epigenetic erasers that remove an acetyl group from histone tails, which then limits the accessibility to DNA at these sites [12]. BCPs are a large family of epigenetic readers that can bind acetylated histones to facilitate recruitment and interactions of TFs [13]. The most extensively studied families of $\mathrm{BCPs}$ are $\mathrm{BD}$ and extra-terminal domain (BET) proteins, consisting of four individual proteins: BRD2, BRD3, BRD4, and BRDT [14].

Numerous small-molecule inhibitors targeting these proteins have been developed based on preclinical work, suggesting the potential to achieve therapeutic benefit in various human disorders $[15,16]$. Because of their reported strong antiproliferative and antioncogenic properties, several inhibitors of these epigenetic targets have been investigated in cancer clinical trials, with some HDAC inhibitors FDA approved for certain malignancies [17]. In addition, HDAC inhibitors (HDACi) and BET protein inhibitors (I-BET) have shown strong efficacy in preclinical models of several inflammatory and autoimmune diseases, such as models of inflammatory bowel disease (IBD) and rheumatoid arthritis (RA) [18-26]. Although several epigenetic inhibitors are being investigated in human trials, relatively few have progressed into clinical practice and thus far exclusively in the cancer field, largely due to the toxicity profile of these compounds [17,27]. Since these first-generation inhibitors typically target multiple members of the HDAC or BET family, unwanted effects may be linked to a broad impact on transcriptional activity that extends to off-target pathways [28,29].

Recently, increasing effort has been dedicated to developing inhibitors that can achieve a higher degree of selectivity in targeting the epigenetic modulators, which may alleviate safety issues that hold back their translation into clinical use [30,31]. Different strategies are being adopted to tackle this challenge: (1) designing isoform-specific or domain-specific inhibitors that can target only single proteins or individual domains in multidomain proteins; (2) developing a targeted approach that can selectively deliver the drug to the relevant proinflammatory cell types that fuel the inflammation in the disease of interest [32]. In this review, we gather the most recent updates regarding these different strategies and we discuss their potential in paving the way towards the next wave of epigenetic drugs, focusing on inflammatory and autoimmune diseases. 
A

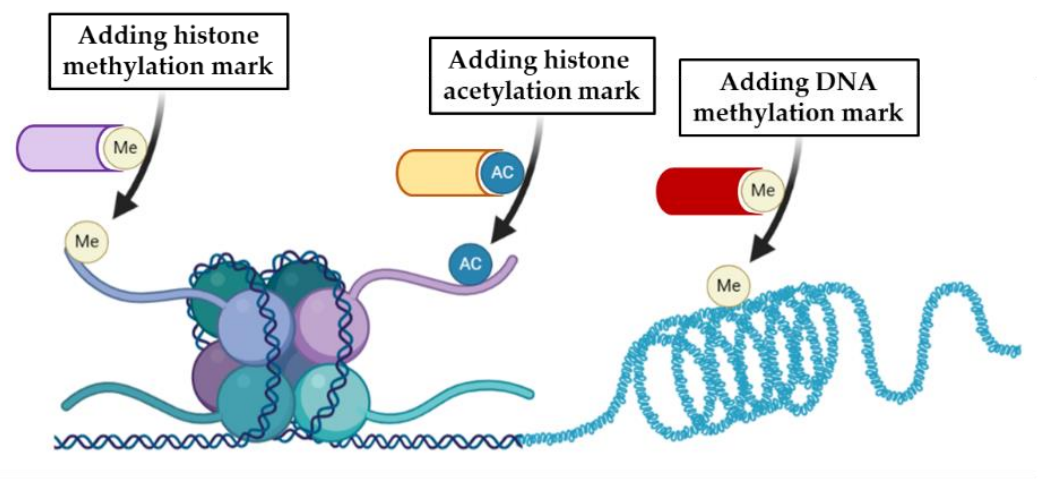

Epigenetic marks:

Me Methylation mark

AC Acetylation mark

Writers:

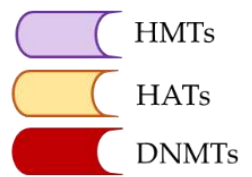

B

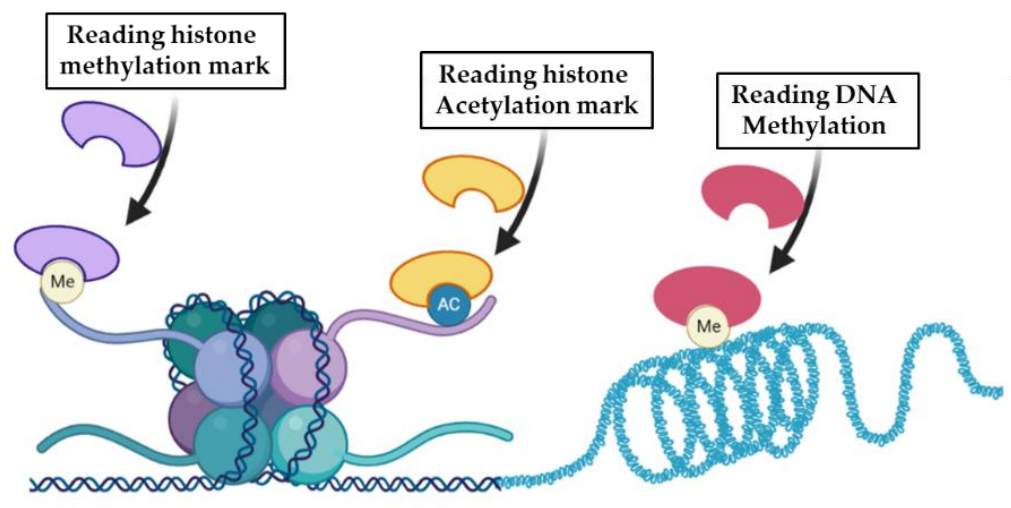

Readers:

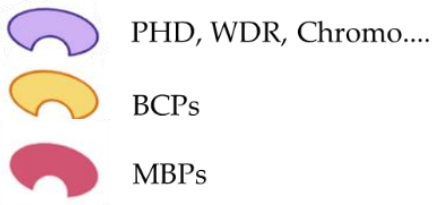

Erasers:

Histone demethylases

HDACs and SIRTs

DNA demethylases

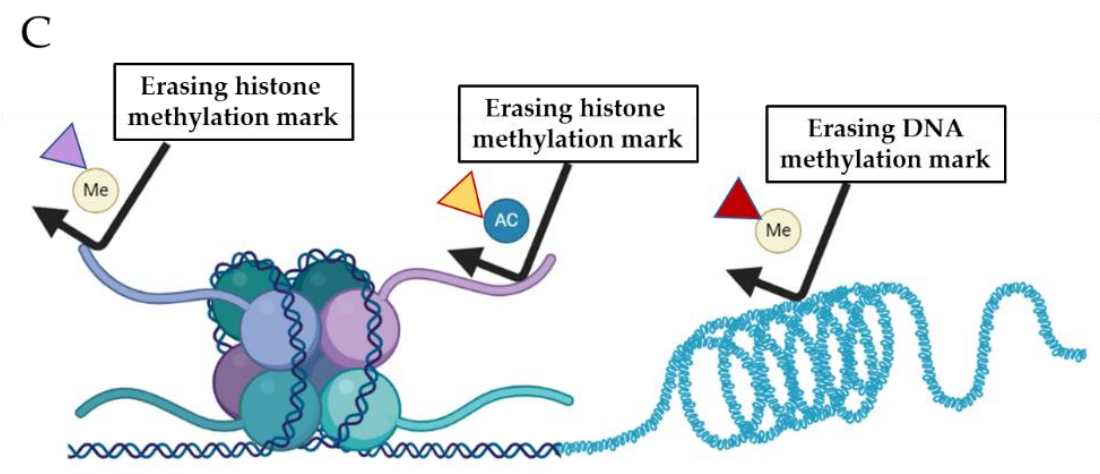

Figure 1. DNA methylation and histone modifications. Post-translational modifications of histones and DNA methylation provide a fine-tuned mechanism for regulating chromatin structure and dynamics. Panel (A) depicts methylation and acetylation of histone tails that involve the addition of methyl group (Me) and acetyl group (AC), respectively. These processes are catalyzed by the epigenetic writers histone methyltransferases (HMTs) and histone acetylases (HATs), respectively. DNA methylation is catalyzed by the epigenetic writers DNA methyltransferases (DNMTs), including DNMT1, DNMT3a, and DNMT3b, which add a methyl group on to the 5-carbon of the cytosine ring. Panel (B) illustrates examples of epigenetic readers that possess specialized domains that recognize specific covalent histone or DNA modifications and respond to upstream signals. Such crosstalk generates a different binding platform for the recruitment of other regulatory proteins, ultimately controlling the chromatin accessibility to transcription factors and gene transcription, such as plant homeodomain (PHD), WD40-repeat (WDR) proteins, and chromo domains that recognize histone methylation marks, broomodomian-containing protiens (BCPs) that recognize histone acetylation marks, and the methyl-CpG-binding proteins (MBPs) that recognize methylation of DNA. Panel (C) shows examples of epigenetic eraser proteins that can remove modifications from DNA or histones to regulate gene expression. 


\section{Methods}

To give an overview of existing selective small-molecule inhibitors targeting HDACs and BCPs and gather the most relevant advances in this direction with focus on their use in inflammatory and autoimmune disease models, we performed a literature review in Medline (PubMed) using "HDAC", "bromodomain", " inhibitor", "selective", "isoform", "class", " esterase sensitive motif" "autoimmune diseases", and "inflammatory diseases" as keywords. Reference lists of existing (systematic) reviews of this topic were searched for additional relevant literature. All included articles were in English. There were no specific inclusion or exclusion criteria for this review. The most referenced articles were selected and are described in the review, with an overview of study characteristics and results shown in Table 1. The figure illustrations were created in BioRender.com.

\section{Advances in HDAC Selective Targeting in Autoimmune and Inflammatory Diseases}

In humans, the HDAC enzymes family comprises 18 members divided into 4 classes: class I HDACs (HDACs 1-3 and 8), class IIa HDACs (HDACs 4, 5, 7, and 9), class IIb HDACs (HDACs 6 and 10), class III sirtuins (Sirt1-7), and class IV HDACs (HDAC11) [12,33,34]. While histone acetyltransferases (HAT) add acetyl groups to lysine residues, thereby permitting TFs binding and subsequent gene expression, histone deacetylases (HDACs) erase histone acetyl residues, leading to chromatin compaction, generally resulting in gene repression $[33,34]$. However, in contrast to the common role of HDACs for gene repression, treatment with HDAC inhibitors typically leads to a reduction rather than increase in proinflammatory gene expression by immune cells [35]. This may be due to global histone hyperacetylation induced by HDACi, which results in over-recruitment of epigenetic readers (in steady state, there is an equilibrium between acetylation and deacetylation) [35]. As a consequence, a large pool of epigenetic readers will be sequestrated nonspecifically, reducing the availability of readers for recruitment to newly induced promoters. This subsequently limits the binding of TFs and gene expression induction at these sites, rendering cells less responsive to external inflammatory stimuli [35], as described in Figure 2. HDAC inhibition was also suggested to reduce cytokine expression by promoting mRNA decay. For instance, Grabiec et al. have shown that pan-HDACi can disrupt IL-6 production in RA fibroblast-like synoviocytes (FLS) by accelerating its mRNA breakdown [36].

HDAC enzymes are key regulators of diverse cellular functions, including the inflammatory response, and their dysregulation has been strongly associated with multiple inflammatory diseases [37]. Current research aims to dissect the biological functions of each individual HDAC with attempts to develop class- or isoform-selective HDACi that can maintain similar anti-inflammatory potency of pan-HDACi while providing a better safety profile [38]. A summary of some of the main selective class or isoform inhibitors of HDACs that have been tested in ex vivo and in vivo animal models of inflammatory and autoimmune diseases is provided in Table 1. An approach for drug delivery to specific cell types has also been developed to limit the off-target activity associated with pan-HDACi. 
A
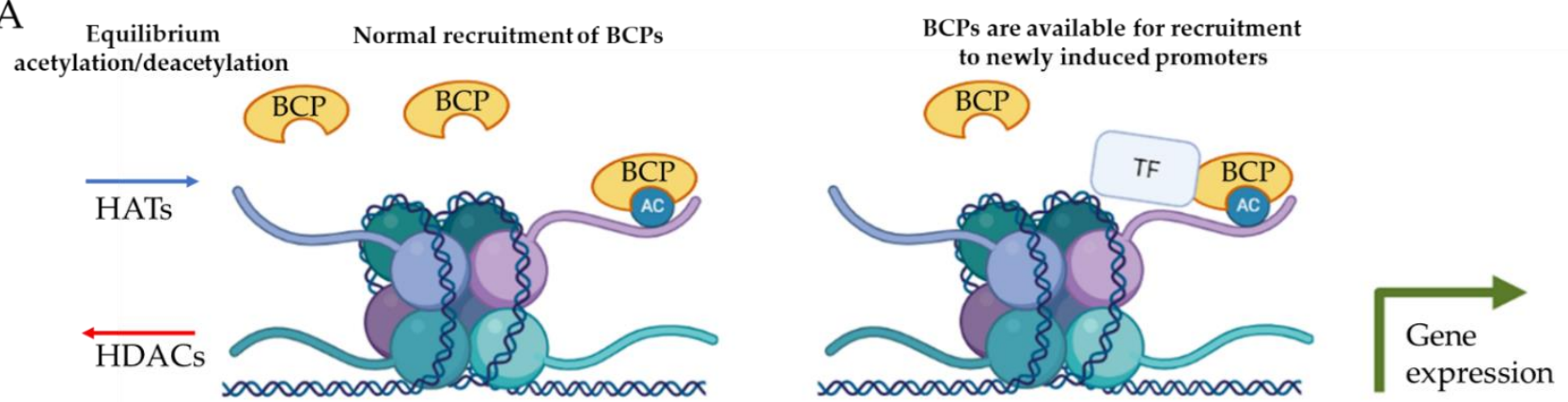

- HDACi

B

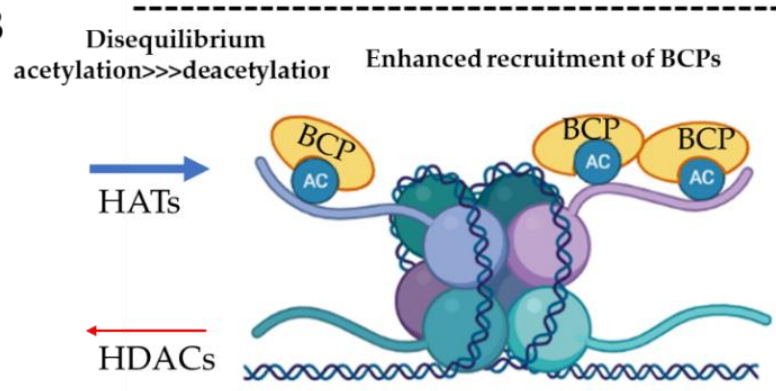

BCPs are unavailable for recruitment to newly induced promoters

\section{+ HDACi}
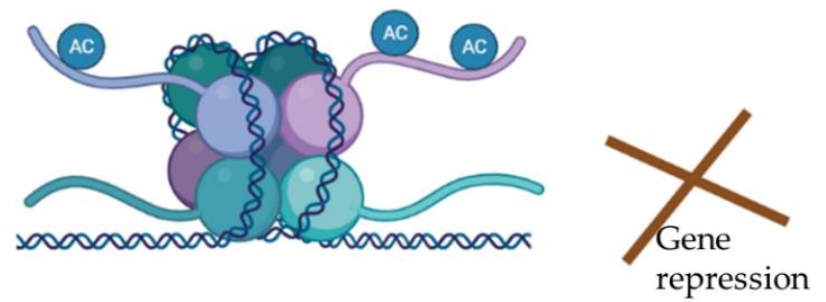

Figure 2. Possible mechanism for inhibition of inflammatory gene expression by HDACi. (A) In steady state, there is an equilibrium between acetylation (AC) and deacetylation, which maintains a pool of epigenetic readers available for recruitment to newly induced promoters, recruitment of transcription factors (TF), and induction of gene expression. (B) Histone deacetylase (HDACs) inhibition increases acetylation of histones that sequester the epigenetic readers, such the bromodomain-containing proteins (BCPs), preventing their recruitment to newly induced promoters.

\subsection{Class-Specific HDACi}

\subsubsection{Class I-Specific HDACi}

Entinostat (MS-275) [39] and Tacedinaline (C1994) [40] are the first potent selective inhibitors of class I HDACs and have shown therapeutic potential by ameliorating inflammation in preclinical models of various inflammatory and autoimmune diseases, including RA [41], Chronic Obstructive Pulmonary Disease (COPD) [42], pancreatitis (19), inflammation associated with angiotensin II-induced hypertension [43], liver fibrosis [44], and lipopolysaccharide-induced acute kidney injury (LPS-AKI) [45]. These beneficial preclinical outcomes were accompanied by a marked reduction in multiple proinflammatory cytokines and leukocyte infiltration [46]. Entinostat treatment reduced cytokine production and suppressed osteoclastic bone resorption in vitro (osteoclast generated from human monocytes), suggesting therapeutic potential in RA and periodontitis [41]. This was borne out by the efficacy of Entinostat in collagen antibody-induced arthritis model where it strongly reduced inflammatory cells infiltration and improved disease score [46]. Notably, Entinostat showed a superior clinical efficacy to pan-HDACi (SAHA) in this model [46]. Similarly, Entinostat was able to significantly affect expression of proinflammatory cytokines in precision-cut lung slices and robustly attenuated inflammatory expression of CXCL1 and neutrophil influx in the lungs in an in vivo mice model of smoking-induced airway inflammation, while the pan-HDACi (SAHA) was without effect in this model [42].

Loh et al. also provided evidence for the importance of class I HDAC inhibition, showing that Entinostat, but not inhibitors of class IIa (PG100) and IIb HDAC (PG50) enzymes, potently suppressed chronic hepatic inflammation and fibrosis in mice [44]. Entinostat has been shown to reduce $\mathrm{CD}^{+} 8^{+}$macrophage infiltration into aortic tissue in 
an angiotensin II-induced hypertension murine model [43]. In Cerulein-induced acute and chronic pancreatitis, Entinostat reduced the infiltration of inflammatory immune cells, including macrophages and $\mathrm{T}$ cells, and directly disrupted macrophage activation [47]. In terms of safety profiles, although no human clinical data are available yet for inflammatory and autoimmune diseases, the class I HDACi Reminostat exhibited an improved safety profile over pan-HDACi in clinical trials in cancer patients showing no cardiac-related toxicities [48,49]. Two class I HDACis; Etinostat and Mocetinostat, initially exhibited cardiac-related events in early studies. However, further evaluation found that the cardiac events were not related to Mocetinostat [50], while for Entinostat cardiac events were attributed to disparities in drug pharmacokinetics compared with preclinical models, which was mitigated upon redesigning the treatment regimens [51,52]. However, a recent trial for metastatic urethral cancer reported pericardial effusion for one patient that was believed to be Mocetinostat-related [53]. Thus, while class I HDACi appears to have fewer side effects than pan-HDACi, adverse events are still apparent, although some caution should be used in interpreting these events in patients with advanced cancer.

\subsubsection{Class II-Specific HDACi}

TMP195 (TFMO 2) is a selective, first-in-class, class IIa HDAC inhibitor reported by Lobera et al. [54]. TMP195 exhibited a potent effect on monocyte and macrophage activation in vitro, reducing CCL2 protein secretion and increasing the production of CCL1 by monocyte-derived macrophages and modifying human monocyte responses to the colony-stimulating factors CSF-1 and CSF-2 in vitro [55]. In an LPS acute injury in vivo model, TMP195 inhibited multiple proinflammatory cytokines/chemokines and accumulation of inflammatory cells in the injured kidney [56]. The reno-protective effects of TMP195 observed in this model suggest that targeting class IIa HDACs might be a novel therapeutic strategy for treating renal inflammation, although further investigation of this hypothesis is required.

\subsection{Isoform-Specific HDACi}

Genetic depletion of individual HDACs has demonstrated that these proteins mediate specific and unique functions [57], suggesting therapeutic relevance for selective isoform targeting. While achieving this is a challenge due to conserved structural similarity between HDAC isoforms [12], HDACi has been reported with selectivity for HDAC1, HDAC2, HDAC3 [33,58-61], HDAC8 [62,63], HDAC6 [64], HDAC11 [65], SIRT1, and SIRT2 [66,67]. However, caution should be taken in interpreting the specificity of the effects of these published inhibitors given the variability of available HDAC assays and the residual dose-dependent effects on other isoforms (Table 1).

\subsubsection{HDAC3 Inhibitors}

Inhibitors with a high degree of reported selectivity toward HDAC3, including RGFP966, MI192, and ITF3100, have been shown to efficiently attenuate inflammatory responses $[33,58,59,68]$ and to restore LPS tolerance in inflammatory macrophages in vitro [33]. RGFP966 has demonstrated efficacy in preclinical models of diabetes [69], osteoarthritis (OA) [70], and allergy [71] via modulating inflammatory pathways. In diabetic mouse models, RGFP-966 was shown to prevent diabetes-associated liver damage, cerebral ischemia, and cardiomyopathy [72-74]. Zhang et al. found that RGFP966 could inhibit the expression of inflammatory markers of OA in rats [70]. Interestingly and unlike pan-HDACi, HDAC3 inhibitor MI192 was able to inhibit the inflammatory response in peripheral blood mononuclear cells (PBMCs) of RA patients but not in PBMCs of healthy control [68]. In line with these observations, inhibition of HDAC3 by the small molecule ITF3100 in RA FLS largely recapitulated the effects of pan-HDACi in suppressing inflammatory gene expression [75]. No effect of HDAC1/2 or HDAC8 inhibition was observed in RA FLS. These data suggest the potential for a clinically relevant advantage of the selective targeting of HDAC3 in RA [75]. 


\subsubsection{HDAC6 Inhibitors}

HDAC6 has been extensively studied in various inflammatory settings, and several small-molecule inhibitors have been designed and reported to be selective, such as BML-281 (CAY10603) [76], Ricolinostat (ACY-1215) [77], CKD-506 [78], Tubastatin A [79], and ACY-738 [80]. HDAC6 inhibition has shown efficiency in multiple preclinical models of inflammatory and autoimmune diseases, including IBD [81-83], RA [84,85], systemic lupus erythematosus (SLE) [78,86], multiple sclerosis [87], lung inflammatory diseases [88,89], allograft rejection [90], skin inflammatory diseases [91], sepsis [92], and acute liver injury [93]. HDAC6 inhibition has been reported to control immune cell recruitment and to modulate $\mathrm{T}$ and $\mathrm{B}$ cell differentiation $[78,83,94]$. In a DSS colitis model, CD19+ $\mathrm{B}$ cell influx into the inflamed colon was reduced in mice treated with BML-281 [83]. In addition, CKD-506 inhibits NF- $\kappa B$ signaling in intestinal epithelial cells and macrophages and ameliorates murine colitis [81]. LTB2 treatment significantly alleviated DSS-induced colitis in mice [82]. Similarly, in a preclinical murine model of SLE, ACY-738 and CKD-506 were able to modulate both $B$ cell and $T$ cell differentiation, restoring aberrant $B$ cell development and enhancing the frequency of splenic Tregs $[78,94]$. In addition, in this model, HDAC6 inhibition significantly reduced inflammatory cytokines such as IL-17 and TNF- $\alpha$ and increased TGF- $\beta$ in serum $[78,94]$. In experimental autoimmune encephalomyelitis (EAE), ACY-738 delayed disease onset and reduced disease severity [87]. BML-281 blocks inflammatory signaling and caspase- 1 activation in the LPS-induced acute lung injury mice model [89].

HDAC6 inhibition impairs effector CD8 T-cell functions during skin inflammation using murine CD8 T cell-related skin disease models, including contact hypersensitivity (CHS) and experimental graft-versus-host disease (GVHD)-like disease [91]. ACY-1215 prevented the development of CHS and GVHD-like disease in vivo by modulating CD8 $\mathrm{T}$ cell activation and functions, abrogating the induction of effector $\mathrm{T}$ cells from naive CD8 T cells [91]. Tubastatin A downregulated Th17 cell function and suppressed acute lung allograft rejection via the HIF-1 $\alpha /$ ROR $\gamma t$ pathway in mice [95]. Notably, this effect was observed only with HDAC6 inhibition but not in HDAC1i-, HDAC3i-, HDAC4i-, and HDAC8i-treated recipients [95]. In a murine model of RA, CKD-506 suppressed monocyte/macrophage inflammatory responses, improved Treg function, and ameliorated arthritis severity [84]. Similarly, Tubastatin A showed significant inhibition of IL-6 in paw tissues of arthritic mice in a collagen-induced arthritis model [96].

Although there are no human clinical studies as yet in inflammatory and autoimmune disease patients, similarly to class I HDACi in patients with cancer, HDAC6 inhibitors exhibit an improved safety profile compared with pan-HDACi [50]. For instance, Ricolinostat has shown no drug-related cardiac events in two clinical trial conducted for multiple myeloma patients either alone or in combination with other drugs [97,98]. Life-threatening cardiac arrhythmias are one of the most limiting factors for the use of pan-HDACi in clinical trials [50]. Pan-HDACi is thought to exert this cardiotoxic effect via inhibition of hERG ion channels either directly [99] or indirectly mediated by transcriptional changes that affect ion channel trafficking [100]. Interestingly selective inhibition of HDAC6 was found to stabilize hERG channel expression, which suggests an application for HDAC6 inhibition in long QT syndrome type 2 treatment [101]. To date, seven registered clinical trials are running for other HDAC6 inhibitors, which will help us to better characterize the safety profile of HDAC6 inhibition.

\subsubsection{HDAC8 Inhibitors}

Some inhibitors of HDAC 8 that have been recently reported have shown a marked anti-inflammatory potential in some preclinical models of inflammatory and autoimmune diseases such as sepsis [63], neuro-inflammation [102], and asthma [100]. WK2-16 [102] and PCI-34051 [103] are reported to be the most selective HDAC8 inhibitors. WK2-16 reduced IL-6, TNF- $\alpha$, and MPP8 expression in both sepsis and LPS-induced neuro-inflammation murine models $[63,102]$ via inhibition of STAT-1/-3 and Akt activation in the absence of an effect on NF-KB or MAPK signaling pathways [63,102]. PCI-34051 was reported to alleviate 
airway inflammation in a preclinical model of asthma by disrupting HDAC8 interaction with Galectin-3, a protein involved in inflammation and pathogenesis of asthma [104].

\subsubsection{Other Isoform-Specific Inhibitors}

Santacruzamate A (CAY10683) is a potent HDAC2 inhibitor, with $>3600$-fold selectivity over other HDACs [105]. Fang-Zhou et al. have demonstrated that Santacruzamate A could suppress neuro-inflammatory responses and TLR4/NF- $\mathrm{kB}$ signaling pathways in an animal model of LPS-induced neuro-inflammation [106]. Other HDAC isoforms are reported to regulate the inflammatory response, including HDAC5 [107] and HDAC10 [108], but as of now there are no specific inhibitors to these isoforms. SIS17 is described as a highly selective HDAC11 inhibitor; however, no data are available on studies with this molecule in preclinical models [109].

Finally, selective inhibitors have been developed for some members of the SIRT family (HDAC class III), including EX-527 and AK 7 that target SIRT1 and SIRT2, respectively [66,67]. Although SIRT1 and SIRT2 are implicated in several inflammatory diseases such as RA and IBD, no data are reported for the use of EX-527 and AK 7 in vitro or in vivo models of inflammation.

\subsection{Cell-Specific Targeted Drug Delivery of Pan-HDACi}

Mononuclear myeloid cells play a key role in the pathogenesis of multiple inflammatory diseases but are also critically required for tissue homeostasis and healing $[110,111]$. Because of the anti-inflammatory activity of HDACi in monocytes/macrophages, selective targeting of these cells could represent an attractive approach for retaining efficacy while minimizing adverse events linked to HDACi in other cell types. A strategy to do so has been developed based on the expression pattern of carboxylesterase 1 (CES1) enzyme (also known as serine esterase 1), which in humans is predominantly expressed in hepatocytes and cells of the mononuclear myeloid lineage, such as monocytes and macrophages, with very little expression reported outside these two sources, mainly in adipose tissue, kidney, and heart [112,113]. CES1 plays a key role in hydrolyzing ester- and amide-bond-containing xenobiotics and drugs [114].

Esterase sensitive motif (ESM) technology has been employed to selectively target CES1-expressing cells. Small-molecule inhibitors are tagged with the ESM motif, the ESMtagged inhibitors enter cells, and when CES1 is expressed, the ESM motif is hydrolyzed into an acid [32] as described in Figure 3. In acid form, the compound is less able to cross the plasma membrane, thus increasing retention and therefore potency in CES1 expressing cells [32] (Figure 3). Such targeted molecules have shown efficacy in a preclinical model of RA in which transgenic mice that express human CES1 under the CD68 promotor were generated to allow human CES1 expression in mononuclear myeloid cells [32]. ESM-HDACi achieved clinical improvement at doses as low as $1 \mathrm{mg} / \mathrm{kg}$ compared with $100 \mathrm{mg} / \mathrm{kg}$ of conventional pan-HDACi (SAHA) needed to achieve a similar clinical response [32]. ESM-HDACi was tolerated up to $30 \mathrm{mg} / \mathrm{kg}$ in vivo dosing [32].

In a phase 1 clinical study, ESM-HDACi proved to be safe and well tolerated while showing efficient and sustainable accumulation in blood monocytes [115]. This sparked the interest to further explore this strategy in other inflammatory disease models. In both acute DSS colitis [116] and acute peritonitis [117] models, ESM-HDACi impaired the differentiation of monocyte in inflamed tissue, which translated into modestly improved colitis [116]. Exploring this strategy in a variety of inflammatory disease models may identify the best application of this approach given the complex role of these cells in mediating the inflammatory response in different diseases $[118,119]$. In addition, using ESM technology with more selective HDAC inhibitors (class or isoform specific) would provide better therapeutic potential. 
A

Non mononuclear myeloid cells (CES1'- immune cells)

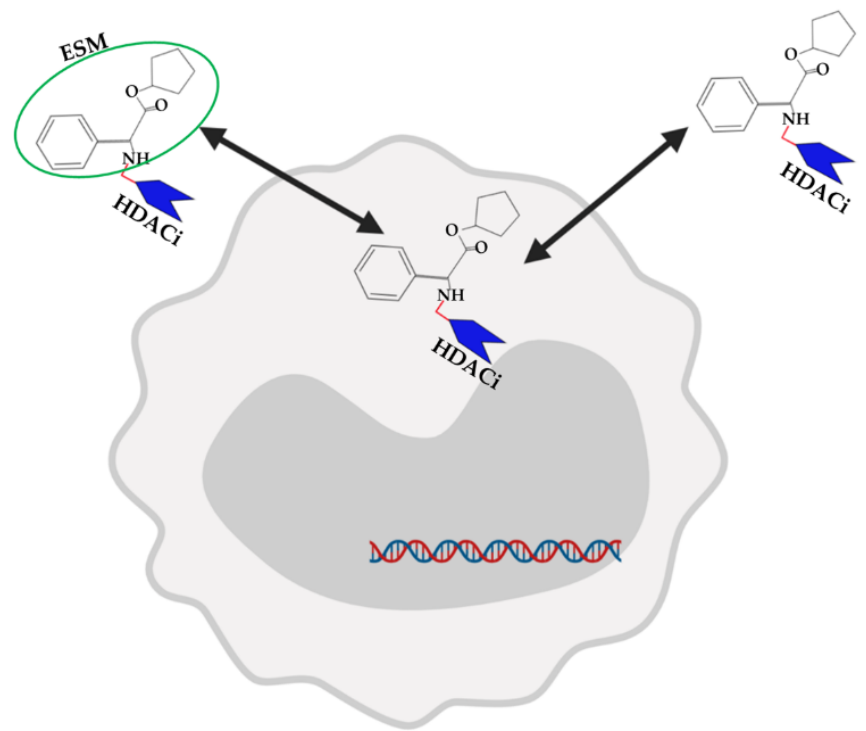

B

Mononuclear myeloid cells (CES1+ immune cells)

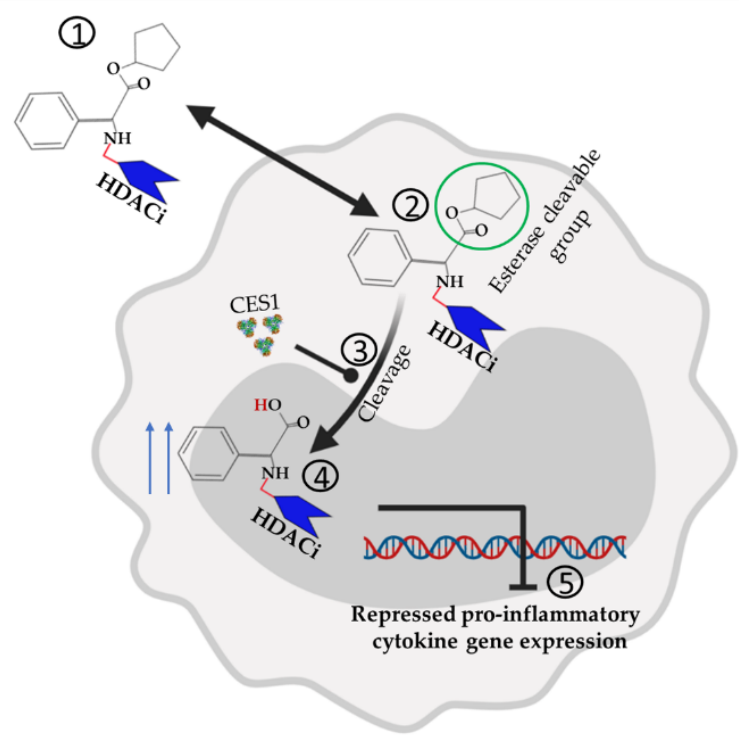

Figure 3. Selective targeting of myeloid cells with HDACi. CES-1 expression in humans is restricted to hepatocytes and cells of the mononuclear myeloid lineage, such as monocytes and macrophages. (A) When ESM-HDACi enters into CES-1-negative cells such as T and B cells, the compound freely diffuses out of the cells; lack of retention of the HDACi minimizes the pharmacological effect. (B) After entry of ESM-HDACi into CES-1-positive cells (1), esters are selectively hydrolyzed by the CES-1 enzyme (2), generating charged acids (3) that are less able to cross the membrane. This leads to intracellular retention of HDACi (4) and enhanced pharmacological effect (e.g., histone hyperacetylation and repression of proinflammatory genes) (5).

\section{Advances in Selective Targeting of BCPs}

$\mathrm{BCPs}$ are group of epigenetic readers that recognize acetylated lysine residues on histone tails and play a role in modulating DNA accessibility to TFs and the transcriptional machinery [120]. Disturbance in BCP function has been reported as a key contributor to a large variety of diseases [15]. In humans, if we exclude splice variants, there are around $56 \mathrm{BDs}$ and $42 \mathrm{BCPs}$ characterized [121]. Based on sequence homology, BCPs are classified into eight different subgroups [120], as described in Figure 4. BCPs are tractable to smallmolecule antagonists that prevent protein-protein interaction between BCPs and acetylated histones and transcription factors [122]. Although numerous compounds targeting BCPs (primarily BET family BCPs) have displayed promising therapeutic potential in preclinical models of cancer and autoimmunity/inflammation, these compounds have not yet been approved by FDA [123]. The majority of BCP inhibitors lack selectivity for individual BCPs or a specific domain, and as BCPs regulate the expression of a plethora of genes and can be ubiquitously expressed, therapeutic translation into the clinic has been restricted by multiple adverse events [121]. To reduce the breadth of effects observed with firstgeneration $\mathrm{BCP}$ inhibitors, efforts have been made to achieve better selectivity amongst BRDs, as well as to develop specific cell type delivery of small molecules targeting BCPs. Three main advances in this direction are discussed below. A summary of some of the main tested selective domain or isoform inhibitors of BCPs in ex vivo and in vivo animal models of inflammatory and autoimmune diseases are described in Table 1. 


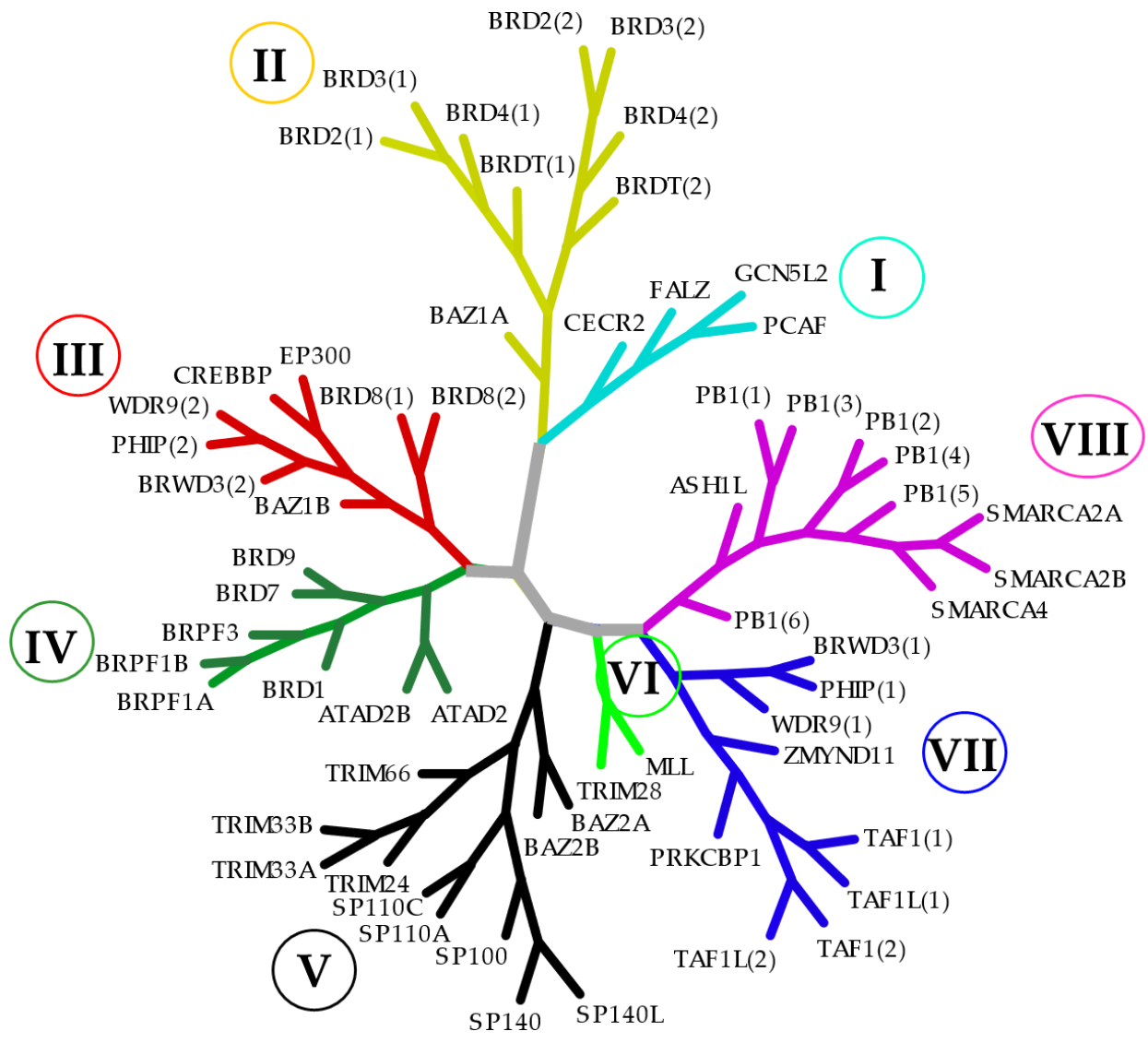

Figure 4. Phylogenetic tree of the human bromodomain-containing protein subgroups. On the basis of sequence homology, BCPs are classified into eight different subgroups (families). The distinct families are indicated by Roman numbers (I-VIII) in circles and illustrated with different colors. 
Table 1. Summary of some of the main tested selective inhibitors of HDACs and BCPs in ex vivo and in vivo models of inflammatory and autoimmune diseases.

\begin{tabular}{|c|c|c|c|c|}
\hline Inhibitors & Targets & Degree of Selectivityin Cell Free Assay & $\begin{array}{c}\text { Preclinical Models of Inflammatory and } \\
\text { Autoimmune Diseases }\end{array}$ & Key Findings \\
\hline \multirow{4}{*}{ Entinostat (MS-275) [39] } & \multirow{4}{*}{ Class I HDAC } & \multirow{4}{*}{$\begin{array}{l}\text { IC50s of 243, 453, and } 248 \mathrm{nM} \text { for HDAC1, } \\
\text { HDAC2, and HDAC3, respectively. }\end{array}$} & $\begin{array}{l}\text { Collagen antibody-induced arthritis (mouse and } \\
\text { rat) [46] }\end{array}$ & $\begin{array}{l}\text { While pan-HDACi (SAHA) could not inhibit } \\
\text { the onset of arthritis, Entinostat displayed } \\
\text { strong antirheumatic activities. }\end{array}$ \\
\hline & & & $\begin{array}{l}\text { Cigarette smoke-induced airway inflammation } \\
\text { (mouse) [42] }\end{array}$ & $\begin{array}{l}\text { While Entinostat attenuated inflammatory } \\
\text { expression and neutrophil influx in the lungs, } \\
\text { pan-HDACi (SAHA) was without effect. }\end{array}$ \\
\hline & & & $\begin{array}{l}\text { Thioacetamide-induced hepatic inflammation } \\
\text { (mouse) [44] }\end{array}$ & $\begin{array}{c}\text { Entinostat but not class IIa and IIb HDACi } \\
\text { suppressed chronic hepatic inflammation and } \\
\text { fibrosis. }\end{array}$ \\
\hline & & & $\begin{array}{l}\text { Cerulein-induced acute and chronic pancreatitis } \\
\text { (mouse) [47] }\end{array}$ & $\begin{array}{c}\text { Reduced infiltration of inflammatory immune } \\
\text { cells. }\end{array}$ \\
\hline Tacedinaline (CI994) [40] & Class I HDAC & $\begin{array}{l}\text { IC50s of } 0.9,0.9,1.2 \text {, and }>20 \mu \mathrm{M} \text { for human } \\
\text { HDAC } 1,2,3 \text {, and } 8 \text {, respectively }\end{array}$ & $\begin{array}{l}\text { Titanium particle-induced calvarial osteolysis } \\
\text { (mouse) [124] }\end{array}$ & $\begin{array}{l}\text { Tacedinaline inhibited osteoclastogenesis } \\
\text { through targeting NF- } \mathrm{kB} \text { and the downstream } \\
\text { c-Fos/NFATc1 signaling pathway. }\end{array}$ \\
\hline TMP195 (TFMO 2) [54] & Class IIa HDAC & $\begin{array}{l}\text { IC50s of 59, 60, 26, and } 15 \mathrm{nM} \text { for HDAC4, } \\
\text { HDAC5, HDAC7, and HDAC9, } \\
\text { respectively. 100-fold selectivity over other } \\
\text { HDACs (IC50s }>10 \mu \mathrm{M})\end{array}$ & $\begin{array}{l}\text { Lipopolysaccharide-induced acute kidney injury } \\
\text { (mouse) [56] }\end{array}$ & $\begin{array}{l}\text { TMP195 inhibited multiple proinflammatory } \\
\text { cytokines/chemokines and reduced } \\
\text { the accumulation of inflammatory immune } \\
\text { cells in the injured kidney. }\end{array}$ \\
\hline \multirow{2}{*}{ RGFP966 [125] } & \multirow{2}{*}{ HDAC3 } & \multirow{2}{*}{$\begin{array}{l}\text { IC50 of } 0.08 \mu \mathrm{M} \text { inhibits HDAC } 3>200 \text {-fold } \\
\text { selectivity over other HDACs }\end{array}$} & Diabetic models (mouse) [72-74] & $\begin{array}{c}\text { RGFP966 prevented diabetes-associated liver } \\
\text { damage, -cerebral ischemia and } \\
\text {-cardiomyopathy. }\end{array}$ \\
\hline & & & Osteoarthritis model (rat) [70] & $\begin{array}{l}\text { RGFP966 inhibited the expression of } \\
\text { inflammatory markers via modulating } \\
\text { HDAC3/NF-kB pathway. }\end{array}$ \\
\hline MI192 [68] & HDAC3 & $\begin{array}{l}\text { IC50s of } 16 \text { and } 30 \mathrm{nM} \text {, for HDAC2 and } \\
\text { HDAC3, respectively. }\end{array}$ & $\begin{array}{l}\text { Ex vivo-stimulated human peripheral blood } \\
\text { mononuclear cells (PBMCs) of RA patients [68] }\end{array}$ & $\begin{array}{l}\text { Unlike pan-HDACi, MI192 inhibited } \\
\text { inflammatory response in PBMC of RA patients } \\
\text { but not in PBMCs of healthy control. }\end{array}$ \\
\hline $\begin{array}{l}\text { Santacruzamate A } \\
\text { (CAY10683) [105] }\end{array}$ & HDAC2 & $\begin{array}{c}\text { IC50 of } 119 \mathrm{pM} \text { for HDAC2 and with } \\
>3600 \text {-fold selectivity over other HDACs. }\end{array}$ & LPS-induced neuro-inflammation (mouse) [106] & $\begin{array}{l}\text { Santacruzamate A suppressed } \\
\text { neuro-inflammatory responses and } \\
\text { TLR4/NF-kB signaling pathways. }\end{array}$ \\
\hline
\end{tabular}


Table 1. Cont.

\begin{tabular}{|c|c|c|c|c|}
\hline Inhibitors & Targets & Degree of Selectivityin Cell Free Assay & $\begin{array}{c}\text { Preclinical Models of Inflammatory and } \\
\text { Autoimmune Diseases }\end{array}$ & Key Findings \\
\hline \multirow[t]{2}{*}{ Tubastatin A [79] } & \multirow[t]{2}{*}{ HDAC6 } & \multirow[t]{2}{*}{$\begin{array}{l}\text { IC50 of } 15 \mathrm{nM} \text { for HDAC6. It is selective } \\
\text { against all the other HDACs (1000-fold) } \\
\text { except HDAC } 8 \text { (57-fold). }\end{array}$} & $\begin{array}{l}\text { Orthotopic lung transplantation model (mouse) } \\
\qquad \text { [95] }\end{array}$ & $\begin{array}{c}\text { Tubastatin A downregulated Th17 cell function } \\
\text { and suppressed acute lung allograft } \\
\text { rejection.Notably, this effect was observed only } \\
\text { with HDAC6 inhibition but not with HDAC1i-, } \\
\text { HDAC3i-, HDAC4i-, and HDAC8i-treated } \\
\text { mice. }\end{array}$ \\
\hline & & & Collagen-induced arthritis (mice) [96] & $\begin{array}{l}\text { Tubastatin A reduced IL-6 in paw tissues of } \\
\text { arthritic mice. }\end{array}$ \\
\hline \multirow[t]{2}{*}{ ACY-738 [80] } & \multirow[t]{2}{*}{ HDAC6 } & \multirow[t]{2}{*}{$\begin{array}{l}\text { IC50 of } 1.7 \mathrm{nM} \text { for HDAC6 and } 60-\text { to } \\
\text { 1500-fold selectivity over class I HDACs }\end{array}$} & $\begin{array}{l}\text { Model of systemic lupus erythematosus (SLE) } \\
\text { (mouse) [94] }\end{array}$ & $\begin{array}{l}\text { ACY-738 modulated both B cell and T cell } \\
\text { differentiation, restored the aberrant B cell } \\
\text { development and enhanced the frequency of } \\
\text { splenic Tregs. }\end{array}$ \\
\hline & & & $\begin{array}{l}\text { Experimental autoimmune encephalomyelitis } \\
\text { model (mouse) [87] }\end{array}$ & $\begin{array}{l}\text { ACY-738 delayed disease onset and reduced } \\
\text { disease severity. }\end{array}$ \\
\hline \multirow[t]{2}{*}{$\begin{array}{l}\text { BML-281 (CAY10603) } \\
{[76]}\end{array}$} & \multirow[t]{2}{*}{ HDAC6 } & \multirow{2}{*}{$\begin{array}{l}\text { IC50s of } 2 \text { pM; for HDAC6. BML-281 also } \\
\text { inhibits HDAC1, HDAC2, HDAC3, } \\
\text { HDAC } 8 \text {, and HDAC10, with IC50s of 271, } \\
\text { 252,0.42, and } 90.7 \mathrm{nM} \text {. }\end{array}$} & DSS-induced colitis (mouse) [83] & $\begin{array}{l}\mathrm{CD} 19^{+} \text {B cell influx into inflamed colon was } \\
\text { reduced in mice treated with BML- } 281 .\end{array}$ \\
\hline & & & LPS-induced acute lung injury (mouse) [89] & $\begin{array}{l}\text { BML-281 blocks inflammatory signaling and } \\
\text { caspase-1 activation. }\end{array}$ \\
\hline LTB2 [82] & HDAC6 & IC50 value of $3.9 \mathrm{nM}$ & DSS-induced colitis (mouse) [82] & LTB2 prevented DSS-induced colitis. \\
\hline $\begin{array}{c}\text { Ricolinostat (ACY-1215) } \\
{[77]}\end{array}$ & HDAC6 & $\begin{array}{c}\text { IC50 of } 5 \mathrm{nM} \text { for HDAC6. Ricolinostat also } \\
\text { inhibits HDAC1, HDAC2, and HDAC3 } \\
\text { with IC50s of 58, 48, and } 51 \mathrm{nM}, \\
\text { respectively. }\end{array}$ & $\begin{array}{c}\text { Contact hypersensitivity (CHS) and experimental } \\
\text { graft-versus-host disease (GVHD)-like disease } \\
\text { (mouse) [91] }\end{array}$ & $\begin{array}{l}\text { Ricolinostat prevented the development of } \\
\text { CHS and GVHD-like disease by modulating } \\
\text { CD8 T cell activation and functions; abrogated } \\
\text { the induction of effector T cells from naive CD8 } \\
\text { T cells }\end{array}$ \\
\hline \multirow[b]{2}{*}{ CKD-506 [78] } & \multirow[b]{2}{*}{ HDAC6 } & \multirow[b]{2}{*}{$\begin{array}{l}\text { IC50 of around } 5 \mathrm{nM} \text {. IC50 values for } \\
\text { HDAC } 1 \text {, HDAC2, HDAC7, and HDAC } 8 \\
\text { were in the range of } 2000-5000 \mathrm{nM} \text {. }\end{array}$} & $\begin{array}{l}\text { DSS- and adoptive T cell transfer-induced colitis } \\
\text { (mouse) [81]. }\end{array}$ & $\begin{array}{l}\text { CKD-506 ameliorated weight loss, disease } \\
\text { activity, and histopathologic score and } \\
\text { downregulated proinflammatory cytokines } \\
\text { production. }\end{array}$ \\
\hline & & & Model of SLE (mouse) [78] & $\begin{array}{l}\text { CKD-506 modulate both B cell and T cell } \\
\text { differentiation, restoring the aberrant B cell } \\
\text { development and enhancing frequency of } \\
\text { splenic Tregs }\end{array}$ \\
\hline
\end{tabular}


Table 1. Cont.

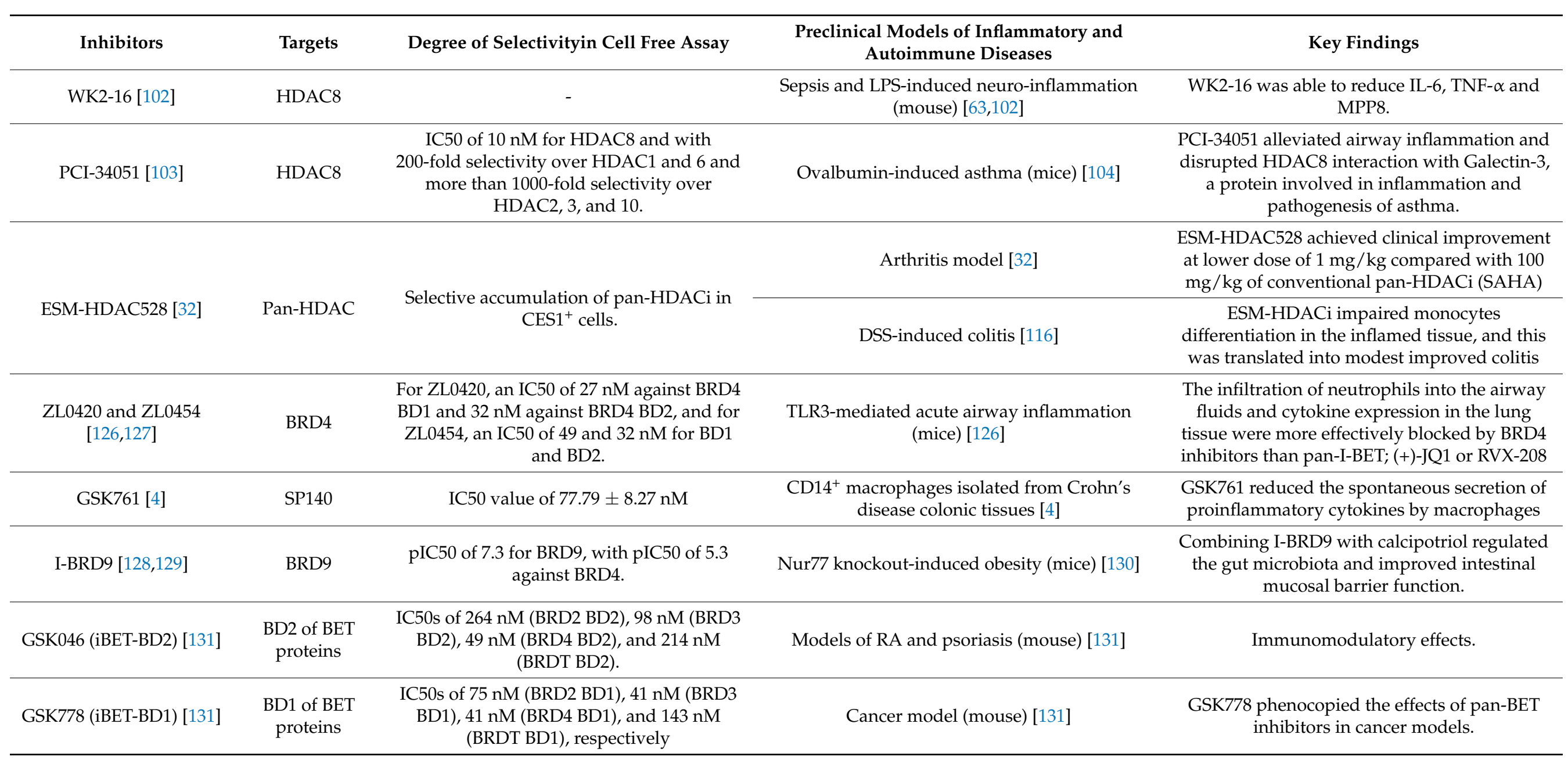




\subsection{Domain-Selective Targeting (BD1 or BD2 Targeting)}

The BET protein family of BCPs comprise the ubiquitously expressed BRD2, BRD3, and BRD4 and the testis-restricted BRDT, all of which harbor two highly conserved tandem bromodomains, BD1 and BD2, allowing them to recognize acetylated lysines [131,132]. BET proteins are well recognized as drug targets for multiple human diseases [131]. Most potent and selective $\mathrm{BCP}$ inhibitors reported target all eight $\mathrm{BDs}$ of the BET family (i.e., BD1 and BD2 in BRD2, 3, 4 and T), and include I-BET762 [133], (+)-JQ1 [134], I-BET151 [122], and I-BET726 [135]. These compounds display similar affinities to BD1 and BD2 [131]. Such compounds have been utilized to demonstrate the function of these proteins in selectively regulating expression of genes with high therapeutic interest for several human inflammatory diseases $[21,131,136]$. Recent reports studying the molecular mechanisms of BET protein binding demonstrate differential binding of BD1 and BD2 to different targets $[121,136]$. These mechanistic studies suggest a model where BD1 is essential for BET protein binding to di-acetylated nucleosomes, while BD2 is more relevant to binding to TFs and protamines $[121,136]$. Therefore, selective inhibition of either BD1 or BD2 binding might promote different functional consequences that allow for more selectivity in functional effect and an improved safety profile to be explored in different diseases settings $[121,136]$.

BD1 and BD2 have high sequence similarity within the acetyl-lysine binding site but exhibit distinct recognition patterns of acetylated histone peptide targets [137]. Accordingly, $\mathrm{BD} 1$ and $\mathrm{BD} 2$ of BRD4 can both recognize acetylated $\mathrm{H} 4$ peptide [137]. However, only $\mathrm{BD} 1$ has been shown to specifically recognize $\mathrm{N}$-terminal-acetylated $\mathrm{H} 4$ peptides in a sequence-dependent manner, while BD2 is more promiscuous [131]. In addition, BD1 favors binding to di-acetylated residues on histone $\mathrm{H} 4$, particularly $\mathrm{H} 4 \mathrm{~K} 5 \mathrm{ac} / \mathrm{K} 8 \mathrm{ac}$, whereas $\mathrm{BD} 2$ is more permissive and can accommodate a variety of di-acetylated peptides [131]. Importantly, despite the ability of BD2 to bind acetylated histones in vitro, biochemical studies have indicated that BD1 of the BET proteins is mainly responsible for chromatin binding $[137,138]$. This suggests that selective inhibition of BD1 or BD2 would be expected to yield distinct subsets of effects other than observed with pan-BET inhibitors [139]. Emerging data with domain-selective inhibitors are providing support for this idea.

ABBV-744 is a BET inhibitor that shows preferential inhibition of the BD2 domain [140]. ABBV-744 has demonstrated a robust activity in prostate cancer xenografts and exhibited fewer platelet and gastrointestinal toxicities compared with the dual-bromodomain BET inhibitors (DbBi) [140]. Recently, Gilan et al. described the development of GSK778 (iBET-BD1) and GSK046 (iBET-BD2), the first highly selective small-molecule inhibitors of BET-BD1 and BET-BD2, respectively [131]. This advance has helped to highlight more distinct roles of BD1 and BD2 (Figure 5). iBET-BD1 showed a selectivity of $\geq 130$-fold for BRD4 BD1, and iBET-BD2 showed selectivity of $\geq 130$-fold for BRD4 BD2 [131]. In this study, iBET-BD1 was able to replicate the effects of pan-BET inhibitor I-BET151 in human cancer cell lines, such as inducing cell cycle arrest and clonogenic capacity [131]. Notably, the effects of iBET-BD2 were less pronounced in this setting [131]. This was explained by the ability of iBET-BD1 to reduce the chromatin binding of all BET proteins, including BRD4, which is known to be critical for maintaining oncogenic and homeostatic transcriptional programs, while iBET-BD2 failed to interfere with BRD 2,3, or 4 binding in an in vitro THP-1 homeostatic model. Interestingly, in the context of inflammatory stimulus-induced in vitro models, iBET-BD2 was able to strongly reduce BRD2 and BRD3 binding while only sparing $\mathrm{BRD} 4$ binding and was able to inhibit the IFN $\gamma$-induced transcriptional program [131]. Despite no effects on cancer cell proliferation or survival, iBET-BD2, like iBET-BD1, exerted immunomodulatory effects by decreasing the expression of proinflammatory cytokines in in vitro assay [131]. These mechanistic studies of BET BD1/BD2 functionality indicate a model where $\mathrm{BD} 1$ binding is sufficient to maintain homeostatic and oncogenic gene transcription programs, while both $\mathrm{BD} 1$ and $\mathrm{BD} 2$ binding is required to promote an inflammatory transcriptional response (Figure 5). This observation implies that selective inhibition of BD2 could be a promising strategy for treatment of inflammatory diseases 
with a potential for an improved safety profile. Indeed, iBET-BD2 was shown to provide efficacy in animal models of RA and psoriasis [131]. Overall, these findings of differential functions for BD1 and BD2 (Figure 5) indicate a therapeutic rationale founded on distinct BET BD-selective targeting in cancer and immuno-inflammatory diseases.

A

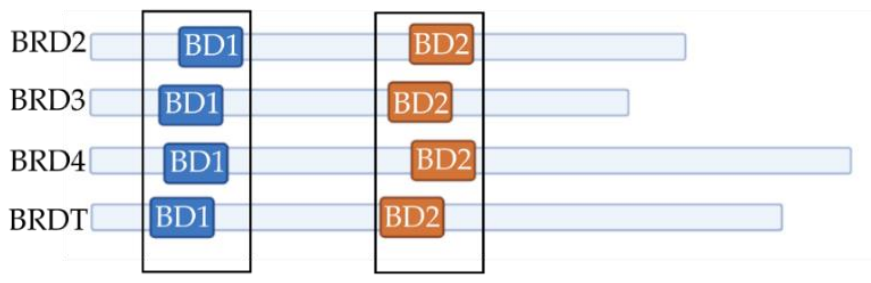

B

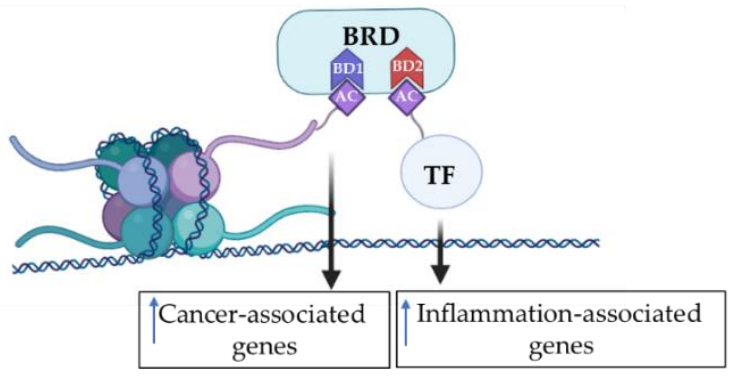

C

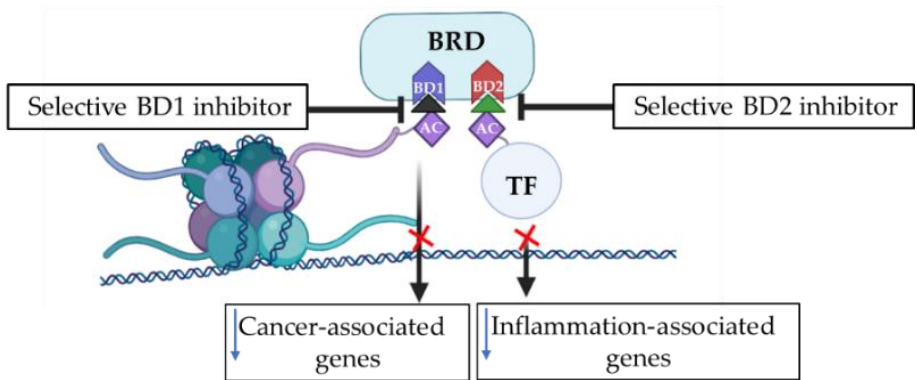

Figure 5. Selective domain targeting of BD1 and BD2. (A) BET proteins family of BCPs comprise the ubiquitously expressed BRD2, BRD3, and BRD4 and BRDT, which all harbor two highly conserved tandem bromodomains, BD1 and BD2, allowing them to recognize acetylated lysine. (B) BD1 and BD2 have distinct functions. BD1 binding is sufficient to maintain homeostatic and oncogenic gene transcription programs, while BD2 binding is required to promote an inflammatory transcriptional response. (C) Domain-selective inhibitors for BD1 and BD2 show preferential effects on different types of cellular functions [141].

\subsection{Selective Targeting of Single BCP}

\subsubsection{BRD4 Inhibitors}

Important advances in new technologies and tools such as assay kits for screening inhibitors, Targetome, BromoMELT, BromoScan assay, and others, have revolutionized the discovery of series of diverse small molecules that selectively target a single BCP. These include ZL0420 and ZL0454, potent selective inhibitors of BRD4 [126,127]. ZL0420 has reported IC50 values of $27 \mathrm{nM}$ against BRD4 BD1 and $32 \mathrm{nM}$ against BRD4 BD2, while ZL0454 shows IC50 value of 49 and $32 \mathrm{nM}$ for BD1 and BD2, respectively [126,127]. These molecules have been utilized to explore the potential of selective targeting of BRD4 in airway inflammation, based on reports of a critical role for BRD4 in NF-kB-mediated epithelial-mesenchymal transition in an in vitro model of airway epithelial cell culture and in in vivo murine models of pulmonary fibrosis and TLR3-mediated acute airway inflammation [27]. Intranasal administration of poly(I:C) induced a substantial increase of total cells and neutrophils into the airway fluids, and cytokine expression in the lung tissue [126]. These changes were more effectively blocked by BRD4 inhibitors than by panI-BET; (+)-JQ1 or RVX-208 [126]. In another study, MS436, a compound that preferentially targets the first bromodomain of BRD4, blocked the transcriptional activity of BRD4 in the NF-KB-directed production of nitric oxide and IL-6 [142]. In addition to the small molecules inhibiting BET BD protein-protein interactions described above, molecules able to degrade BET proteins based on PROTAC technology have been developed. Notably, some of these have been reported to have BET isoform selectivity, such dBET57 [143] and QCA570 [144], which have been reported to selectively degrade BRD4. To date, however, no in vivo studies with these molecules are reported. 


\subsubsection{SP140 Inhibitor}

The development of inhibitors targeting BCPs proteins other than BET in inflammatory and autoimmune diseases are rare, although some advances have been reported. Another $\mathrm{BCP}$ with reported therapeutic potentials is speckled $140 \mathrm{KDa}$ (SP140), which belongs to the SP100 family of proteins that also includes SP100, SP110, and SP140 L [4]. Genetic and epigenetic alterations in the SP140 locus have been strongly associated with autoimmune and inflammatory diseases, including Crohn's disease (CD) and multiple sclerosis $[145,146]$. SP140 is predominantly expressed in immune cells, suggesting an interesting therapeutic potential [4]. Ghiboub et al. have described the first selective small-molecule inhibitor of SP140 (GSK761). GSK761 was shown to compete with the N-terminal tail of histone H3 for interactions with the SP140 BRD-PHD module [4]. GSK761 decreased the differentiation of monocytes into inflammatory macrophages and LPS-induced inflammatory activation, whilst inducing the generation of $\mathrm{CD}^{2} \mathrm{C6}^{+}$regulatory macrophages that mark anti-TNF remission induction in CD patients. Notably, ex vivo treatment of $\mathrm{CD} 14^{+}$macrophages isolated from CD intestinal mucosa with GSK761 inhibited the spontaneous expression of cytokines, including TNF [4]. While this study identifies SP140 as a druggable epigenetic reader and potential therapeutic target for CD, GSK761 however shows poor in vivo pharmacokinetics, potentially restricting its use in vivo [4].

\subsubsection{BRD9 Inhibitors}

BRD9 is part of the SWI/SNF remodeling BAF complex [147], and selective BRD9 inhibitors, I-BRD9 and BI-7273, have been described [128,129]. Evidence for the importance of BRD9 in immune function has come from studies in the T cell transfer colitis model, where $\mathrm{T}$ effector cells were co-transferred with either BRD9-depleted or normal Treg cells [148]. Notably, BRD9-deficient Tregs, unlike control Tregs, failed to prevent colitis development in recipient mice. [148]. As BRD9-deficient Tregs were also defective in the context of tumor immunity, the authors suggested that small-molecule drugs could be useful to fight cancer. Interestingly, a study by Qingqing Lv et al. showed that calcipotriol combined with I-BRD9 can regulate the gut microbiota, improve intestinal mucosal barrier function, and reduce LPS absorption into the blood [130].

\subsubsection{CREB Inhibitor}

The BCP cyclic AMP response element-binding protein (CREB) is a transcriptional coactivator of many different transcription factors and plays an essential role in regulating the immune response [149], including mediating TNF- $\alpha$ and IL-10 production in macrophages and controlling cytokine expression by Th1 (IL-2 and IFN- $\gamma$ ) and Th2 cells (IL4 and IL-13) through the regulation of IFN- $\gamma$ production [149]. Dysregulation of CREB has been associated with several immune-mediated diseases [149-151]. For instance, CREB was shown to play a role in synovial cell hyperfunction in patients with RA [151] and intestinal barrier dysfunction in IBD [150]. Thus, targeting CREB selectively may yield therapeutic benefits for inflammatory diseases. PF-CBP1 and KG-501 have been reported as potent selective inhibitors of CREB by Eugene L et al. [152] and Jennifer L et al. [153], respectively. These compounds target specifically the BD in CREB protein [152,153]. PF-CBP1 demonstrated strong potential to reduce proinflammatory cytokines in human macrophages in vitro [152]. Notably, the authors observed several other genes that were affected by PF-CBP1 but not by pan-BET inhibitor, including REL, RELB, CCL2, CCL3, MRC1, and NFKBIA [152]. These data highlight the effects of CBP pharmacological inhibition on specific and distinct molecular targets and suggest that $\mathrm{CBP}$ inhibitors could be used to investigate therapeutic opportunities in inflammation that possess a molecular etiology mechanistically different to BET-associated inflammation.

\subsubsection{BRPF Inhibitors}

BRD and plant homeodomain finger-containing (BRPF) family proteins consist of three members: BRPF1, BRPF2 (BRD1), and BRPF3 [154]. Julia et al. have reported three 
potent and selective inhibitors: one (PFI-4) with high selectivity for the BRPF1B isoform and two pan-BRPF bromodomain inhibitors (OF-1, NI-57) [155]. Intriguingly, the inhibitors impaired RANKL-induced differentiation of primary murine bone marrow cells and human primary monocytes into bone-resorbing osteoclasts by specifically repressing transcriptional programs required for osteoclastogenesis [155].

\subsection{Cell-Specific Targeted Drug Delivery of I-BET}

As discussed above, the ESM technology can be used to preferentially target smallmolecule inhibitors to myeloid cells. GlaxoSmithKline has utilized this approach to generate myeloid-targeted ESM-I-BET compounds [156]. However, no preclinical data are available yet for these compounds [156].

\section{Conclusions/Perspectives}

While progress is being made regarding the development of more isoform/domainselective HDAC and BCP inhibitors, further pre- and clinical studies of these molecules are required to better characterize their efficacy and safety profiles. Although new HDAC and $\mathrm{BCP}$ inhibitors display high affinity towards specific classes, isoforms, or domains, most still retain residual effects on one or more other epigenetic enzymes, as described in the Table 1. Thus, efforts should continue towards developing new isoform/domain-selective inhibitors with improved specificity to avoid potential off-target effects. Meanwhile, two valuable approaches for future studies can help improve safety and guide applications into the inflammatory disease field. The first approach would involve examining individual HDAC and BCP expressions in different inflammatory diseases, as reviewed for IBD here [157]. This may better identify the relevant individual HDAC/BCP for each disease setting and guide selective inhibitor design to target the relevant isoform/domain for each disease. A second approach would involve conducting transcriptional analysis studies that compare the impact of individual isoform/domain knockdowns/inhibitions in different in vitro and in vivo systems. This can help to identify targets that show efficient modulation of inflammatory pathways without impacting other central/homeostatic pathways upon their inhibition. Results from such studies can guide the development and application of further selective HDAC/BCP inhibitors in inflammatory and autoimmune diseases.

Author Contributions: Conceptualization, W.J.d.J., M.G. and A.M.I.E.; writing-original draft preparation, M.G., D.F.T., N.R.H. and A.M.I.E.; review and editing, W.J.d.J., D.F.T., N.R.H. and M.P.J.d.W.; supervision, W.J.d.J.; Figure preparation, M.G. All authors have read and agreed to the published version of the manuscript.

Funding: M.G. and A.M.I.F. are funded by European Union's Horizon 2020 research and innovation program under Grant Agreement No. ITN-2014-EID-641665. W.J.d.J. is funded by Dutch Ministry of Economic Affairs, LSH-TKI, Health Holland.

Institutional Review Board Statement: Not applicable.

Informed Consent Statement: Not applicable.

Data Availability Statement: Not applicable.

Conflicts of Interest: The authors declare no conflict of interest.

\footnotetext{
Abbreviations

HDAC: histone deacetylase; BD: bromodomain; BRD: BET bromodomain-containing protein; IC50: half-maximal inhibitory concentration; SP140: speckled $140 \mathrm{KDa}$, CES1: carboxylesterase 1; BCP: Bromodomain containing protein.
} 


\section{References}

1. Kondilis-Mangum, H.D.; Wade, P.A. Epigenetics and the adaptive immune response. Mol. Asp. Med. 2013, 34, 813-825. [CrossRef] [PubMed]

2. Lang, K.S.; Burow, A.; Kurrer, M.; Lang, P.A.; Recher, M. The role of the innate immune response in autoimmune disease. J. Autoimmun. 2007, 29, 206-212. [CrossRef] [PubMed]

3. Chen, Z.; Li, S.; Subramaniam, S.; Shyy, J.Y.; Chien, S. Epigenetic Regulation: A New Frontier for Biomedical Engineers. Annu. Rev. Biomed. Eng. 2017, 19, 195-219. [CrossRef] [PubMed]

4. Ghiboub, M.; Koster, J.; Craggs, P.D.; Li Yim, A.Y.F.; Shillings, A.; Hutchinson, S.; Bingham, R.P.; Gatfield, K.; Hageman, I.L.; Yao, G.; et al. Modulation of macrophage inflammatory function through selective inhibition of the epigenetic reader protein SP140. bioRxiv 2020. [CrossRef]

5. Shanmugam, M.K.; Sethi, G. Role of epigenetics in inflammation-associated diseases. Subcell Biochem. 2013, 61, 627-657.

6. Holoch, D.; Moazed, D. RNA-mediated epigenetic regulation of gene expression. Nat. Rev. Genet. 2015, 16, 71-84. [CrossRef]

7. Zeng, Y.; Chen, T. DNA Methylation Reprogramming during Mammalian Development. Genes 2019, 10, 257. [CrossRef]

8. Bannister, A.J.; Kouzarides, T. Regulation of chromatin by histone modifications. Cell Res. 2011, 21, 381-395. [CrossRef]

9. Araki, Y.; Mimura, T. The Histone Modification Code in the Pathogenesis of Autoimmune Diseases. Mediat. Inflamm. 2017, 2017, 1-12. [CrossRef]

10. Hull, E.E.; Montgomery, M.R.; Leyva, K.J. HDAC Inhibitors as Epigenetic Regulators of the Immune System: Impacts on Cancer Therapy and Inflammatory Diseases. BioMed Res. Int. 2016, 2016, 1-15. [CrossRef]

11. Morgado-Pascual, J.L.; Rayego-Mateos, S.; Tejedor, L.; Suarez-Alvarez, B.; Ruiz-Ortega, M. Bromodomain and Extraterminal Proteins as Novel Epigenetic Targets for Renal Diseases. Front. Pharm. 2019, 10, 1315. [CrossRef]

12. Seto, E.; Yoshida, M. Erasers of Histone Acetylation: The Histone Deacetylase Enzymes. Cold Spring Harb. Perspect. Biol. 2014, 6, a018713. [CrossRef]

13. Ferri, E.; Petosa, C.; McKenna, C.E. Bromodomains: Structure, function and pharmacology of inhibition. Biochem. Pharm. 2016, 106, 1-18. [CrossRef]

14. Filippakopoulos, P.; Knapp, S. Targeting bromodomains: Epigenetic readers of lysine acetylation. Nat. Rev. Drug Discov. 2014, 13, 337-356. [CrossRef]

15. Muller, S.; Filippakopoulos, P.; Knapp, S. Bromodomains as therapeutic targets. Expert Rev. Mol. Med. 2011, 13, e29. [CrossRef]

16. Hancock, W.W.; Akimova, T.; Beier, U.H.; Liu, Y.; Wang, L. HDAC inhibitor therapy in autoimmunity and transplantation. Ann. Rheum. Dis. 2012, 71 (Suppl. 2), i46-i54. [CrossRef]

17. Singh, A.K.; Bishayee, A.; Pandey, A.K. Targeting Histone Deacetylases with Natural and Synthetic Agents: An Emerging Anticancer Strategy. Nutrients 2018, 10, 731. [CrossRef]

18. Glauben, R.; Batra, A.; Fedke, I.; Zeitz, M.; Lehr, H.A.; Leoni, F.; Mascagni, P.; Fantuzzi, G.; Dinarello, C.A.; Siegmund, B. Histone Hyperacetylation Is Associated with Amelioration of Experimental Colitis in Mice. J. Immunol. 2006, 176, 5015-5022. [CrossRef]

19. Nadeem, A.; Al-Harbi, N.O.; Al-Harbi, M.M.; El-Sherbeeny, A.M.; Ahmad, S.F.; Siddiqui, N.; Ansari, M.A.; Zoheir, K.M.; Attia, S.M.; Al-Hosaini, K.A.; et al. Imiquimod-induced psoriasis-like skin inflammation is suppressed by BET bromodomain inhibitor in mice through RORC/IL-17A pathway modulation. Pharm. Res. 2015, 99, 248-257. [CrossRef]

20. Rudman, M.D.; Choi, J.S.; Lee, H.E.; Tan, S.K.; Ayad, N.G.; Lee, J.K. Bromodomain and extraterminal domain-containing protein inhibition attenuates acute inflammation after spinal cord injury. Exp. Neurol. 2018, 309, 181-192. [CrossRef]

21. Copsel, S.N.; Lightbourn, C.O.; Barreras, H.; Lohse, I.; Wolf, D.; Bader, C.S.; Manov, J.; Kale, B.J.; Shah, D.; Brothers, S.P.; et al BET Bromodomain Inhibitors Which Permit Treg Function Enable a Combinatorial Strategy to Suppress GVHD in Pre-clinical Allogeneic HSCT. Front. Immunol. 2019, 9, 3104. [CrossRef] [PubMed]

22. Friedrich, M.; Gerbeth, L.; Gerling, M.; Rosenthal, R.; Steiger, K.; Weidinger, C.; Keye, J.; Wu, H.; Schmidt, F.; Weichert, W.; et al. HDAC inhibitors promote intestinal epithelial regeneration via autocrine TGF $\beta 1$ signalling in inflammation. Mucosal Immunol. 2019, 12, 656-667. [CrossRef] [PubMed]

23. Cui, S.-N.; Chen, Z.-Y.; Yang, X.-B.; Chen, L.; Yang, Y.-Y.; Pan, S.-W.; Wang, Y.-X.; Xu, J.-Q.; Zhou, T.; Xiao, H.-R.; et al. Trichostatin A modulates the macrophage phenotype by enhancing autophagy to reduce inflammation during polymicrobial sepsis. Int. Immunopharmacol. 2019, 77, 105973. [CrossRef]

24. Ali, M.N.; Choijookhuu, N.; Takagi, H.; Srisowanna, N.; Huynh, M.N.N.; Yamaguchi, Y.; Oo, P.S.; Kyaw, M.T.H.; Sato, K.; Yamaguchi, R.; et al. The HDAC Inhibitor, SAHA, Prevents Colonic Inflammation by Suppressing Pro-inflammatory Cytokines and Chemokines in DSS-induced Colitis. Acta Histochem. Cytochem. 2018, 51, 33-40. [CrossRef] [PubMed]

25. Jahagirdar, R.; Attwell, S.; Marusic, S.; Bendele, A.; Shenoy, N.; McLure, K.G.; Gilham, D.; Norek, K.; Hansen, H.C.; Yu, R.; et al. RVX-297, a BET Bromodomain Inhibitor, Has Therapeutic Effects in Preclinical Models of Acute Inflammation and Autoimmune Disease. Mol. Pharm. 2017, 92, 694-706. [CrossRef] [PubMed]

26. Schilderink, R.; Bell, M.; Reginato, E.; Patten, C.; Rioja, I.; Hilbers, F.W.; Kabala, P.A.; Reedquist, K.A.; Tough, D.F.; Tak, P.P.; et al. BET bromodomain inhibition reduces maturation and enhances tolerogenic properties of human and mouse dendritic cells. Mol. Immunol. 2016, 79, 66-76. [CrossRef] [PubMed]

27. Yan, L.; Wang, F.; Xiaoxue, C.; Wang, J.; Zhao, Y.; Li, Y.; He, B. Zinc-dependent Deacetylase (HDAC) Inhibitors with Different Zinc Binding Groups. Curr. Top. Med. Chem. 2019, 19, 223-241. 
28. Subramanian, S.; Bates, S.E.; Wright, J.J.; Espinoza-Delgado, I.; Piekarz, R.L. Clinical Toxicities of Histone Deacetylase Inhibitors. Pharmaceuticals 2010, 3, 2751-2767. [CrossRef]

29. van Veggel, M.; Westerman, E.; Hamberg, P. Clinical Pharmacokinetics and Pharmacodynamics of Panobinostat. Clin. Pharm. 2018, 57, 21-29. [CrossRef]

30. Pervaiz, M.; Mishra, P.; Günther, S. Bromodomain Drug Discovery-The Past, the Present, and the Future. Chem. Rec. 2018, 18, 1808-1817. [CrossRef]

31. Andrieu, G.; Belkina, A.C.; Denis, G.V. Clinical trials for BET inhibitors run ahead of the science. Drug Discov. Today Technol. 2016, 19, 45-50. [CrossRef]

32. Needham, L.A.; Davidson, A.H.; Bawden, L.J.; Belfield, A.; Bone, E.A.; Brotherton, D.H.; Bryant, S.; Charlton, M.H.; Clark, V.L.; Davies, S.J.; et al. Drug Targeting to Monocytes and Macrophages Using Esterase-Sensitive Chemical Motifs. J. Pharm. Exp. 2011, 339, 132-142. [CrossRef]

33. Ghiboub, M.; Zhao, J.; Yim, A.Y.F.L.; Schilderink, R.; Verseijden, C.; van Hamersveld, P.H.P.; Duarte, J.M.; Hakvoort, T.B.M.; Admiraal, I.; Harker, N.R.; et al. HDAC3 Mediates the Inflammatory Response and LPS Tolerance in Human Monocytes and Macrophages. Front. Immunol. 2020, 11, 550769. [CrossRef]

34. Park, S.-Y.; Kim, J.-S. A short guide to histone deacetylases including recent progress on class II enzymes. Exp. Mol. Med. 2020, 52, 204-212. [CrossRef]

35. Marié, I.J.; Chang, H.-M.; Levy, D.E. HDAC stimulates gene expression through BRD4 availability in response to IFN and in interferonopathies. J. Exp. Med. 2018, 215, 3194-3212. [CrossRef]

36. Grabiec, A.M.; Korchynskyi, O.; Tak, P.P.; Reedquist, K.A. Histone deacetylase inhibitors suppress rheumatoid arthritis fibroblastlike synoviocyte and macrophage IL-6 production by accelerating mRNA decay. Ann. Rheum. Dis. 2011, 71, 424-431. [CrossRef]

37. Tang, J.; Yan, H.; Zhuang, S. Histone deacetylases as targets for treatment of multiple diseases. Clin. Sci. 2013, 124, 651-662. [CrossRef]

38. Cao, F.; Zwinderman, M.R.; Van Merkerk, R.; Ettema, P.E.; Quax, W.J.; Dekker, F.J. Inhibitory selectivity among class I HDACs has a major impact on inflammatory gene expression in macrophages. Eur. J. Med. Chem. 2019, 177, 457-466. [CrossRef]

39. Saito, A.; Yamashita, T.; Mariko, Y.; Nosaka, Y.; Tsuchiya, K.; Ando, T.; Suzuki, T.; Tsuruo, T.; Nakanishi, O. A synthetic inhibitor of histone deacetylase, MS-27-275, with marked in vivo antitumor activity against human tumors. Proc. Natl. Acad. Sci. USA 1999, 96, 4592-4597. [CrossRef]

40. Moradei, O.M.; Mallais, T.C.; Frechette, S.; Paquin, I.; Tessier, P.E.; Leit, S.M.; Fournel, M.; Bonfils, C.; Trachy-Bourget, M.-C.; Liu, J.; et al. Novel Aminophenyl Benzamide-Type Histone Deacetylase Inhibitors with Enhanced Potency and Selectivity. J. Med. Chem. 2007, 50, 5543-5546. [CrossRef]

41. Cantley, M.D.; Fairlie, D.P.; Bartold, P.M.; Marino, V.; Gupta, P.K.; Haynes, D.R. Inhibiting histone deacetylase 1 suppresses both inflammation and bone loss in arthritis. Rheumatology 2015, 54, 1713-1723. [CrossRef] [PubMed]

42. Leus, N.G.J.; Bosch, T.V.D.; van der Wouden, P.E.; Krist, K.; Ourailidou, M.E.; Eleftheriadis, N.; Kistemaker, L.E.M.; Bos, S.; Gjaltema, R.A.F.; Mekonnen, S.A.; et al. HDAC1-3 inhibitor MS-275 enhances IL10 expression in RAW264.7 macrophages and reduces cigarette smoke-induced airway inflammation in mice. Sci. Rep. 2017, 7, 45047. [CrossRef] [PubMed]

43. Ryu, Y.; Kee, H.J.; Sun, S.; Seok, Y.M.; Choi, S.Y.; Kim, G.R.; Kee, S.-J.; Pflieger, M.; Kurz, T.; Kim, H.-S.; et al. Class I histone deacetylase inhibitor MS-275 attenuates vasoconstriction and inflammation in angiotensin II-induced hypertension. PLoS ONE 2019, 14, e0213186. [CrossRef] [PubMed]

44. Loh, Z.; Fitzsimmons, R.L.; Reid, R.C.; Ramnath, D.; Clouston, A.; Gupta, P.K.; Irvine, K.M.; Powell, E.E.; Schroder, K.; Stow, J.L.; et al. Inhibitors of class I histone deacetylases attenuate thioacetamide-induced liver fibrosis in mice by suppressing hepatic type 2 inflammation. Br. J. Pharm. 2019, 176, 3775-3790. [CrossRef] [PubMed]

45. Zhang, H.; Zhang, W.; Jiao, F.; Li, X.; Zhang, H.; Wang, L.; Gong, Z. The Nephroprotective Effect of MS-275 on Lipopolysaccharide (LPS)-Induced Acute Kidney Injury by Inhibiting Reactive Oxygen Species (ROS)-Oxidative Stress and Endoplasmic Reticulum Stress. Med. Sci. Monit. 2018, 24, 2620-2630. [CrossRef] [PubMed]

46. Lin, H.-S.; Hu, C.-Y.; Chan, H.-Y.; Liew, Y.-Y.; Huang, H.-P.; Lepescheux, L.; Bastianelli, E.; Baron, R.; Rawadi, G.; Clément-Lacroix, P. Anti-rheumatic activities of histone deacetylase (HDAC) inhibitors in vivo in collagen-induced arthritis in rodents. Br. J. Pharm. 2007, 150, 862-872. [CrossRef] [PubMed]

47. Bombardo, M.; Saponara, E.; Malagola, E.; Chen, R.; Seleznik, G.M.; Haumaitre, C.; Quilichini, E.; Zabel, A.; Reding, T.; Graf, R.; et al. Class I histone deacetylase inhibition improves pancreatitis outcome by limiting leukocyte recruitment and acinar-to-ductal metaplasia. Br. J. Pharm. 2017, 174, 3865-3880. [CrossRef]

48. Walewski, J.; Paszkiewicz-Kozik, E.; Borsaru, G.; Hellmann, A.; Janikova, A.; Warszewska, A.; Mais, A.; Ammendola, A.; Herz, T.; Krauss, B.; et al. Resminostat in patients with relapsed or refractory Hodgkin lymphoma: Results of the phase II SAPHIRE study. Leuk. Lymphoma 2019, 60, 675-684. [CrossRef]

49. Kitazono, S.; Fujiwara, Y.; Nakamichi, S.; Mizugaki, H.; Nokihara, H.; Yamamoto, N.; Yamada, Y.; Inukai, E.; Nakamura, O.; Tamura, T. A phase I study of resminostat in Japanese patients with advanced solid tumors. Cancer Chemother. Pharm. 2015, 75, 1155-1161. [CrossRef]

50. Boumber, Y.; Younes, A.; Garcia-Manero, G. Mocetinostat (MGCD0103): A review of an isotype-specific histone deacetylase inhibitor. Expert Opin. Investig. Drugs 2011, 20, 823-829. [CrossRef] 
51. Knipstein, J.; Gore, L. Entinostat for treatment of solid tumors and hematologic malignancies. Expert Opin. Investig. Drugs 2011, 20, 1455-1467. [CrossRef]

52. Ruiz, R.; Raez, E.L.; Rolfo, C. Entinostat (SNDX-275) for the treatment of non-small cell lung cancer. Expert Opin. Investig. Drugs 2015, 24, 1101-1109. [CrossRef]

53. Giannopoulou, A.F.; Velentzas, A.D.; Konstantakou, E.G.; Avgeris, M.; Katarachia, S.A.; Papandreou, N.C.; Kalavros, N.I.; Mpakou, V.E.; Iconomidou, V.; Anastasiadou, E.; et al. Revisiting Histone Deacetylases in Human Tumorigenesis: The Paradigm of Urothelial Bladder Cancer. Int. J. Mol. Sci. 2019, 20, 1291. [CrossRef]

54. Lobera, M.; Madauss, K.P.; Pohlhaus, D.T.; Wright, Q.G.; Trocha, M.; Schmidt, D.R.; Baloglu, E.; Trump, R.P.; Head, M.S.; Hofmann, G.A.; et al. Selective class IIa histone deacetylase inhibition via a nonchelating zinc-binding group. Nat. Chem. Biol. 2013, 9, 319-325. [CrossRef]

55. Guerriero, J.L.; Sotayo, A.; Ponichtera, H.E.; Castrillon, J.A.; Pourzia, A.L.; Schad, S.; Johnson, S.F.; Carrasco, R.D.; Lazo, S.; Bronson, R.T.; et al. Class IIa HDAC inhibition reduces breast tumours and metastases through anti-tumour macrophages. Nat. Cell Biol. 2017, 543, 428-432. [CrossRef]

56. Zhang, W.; Guan, Y.; Bayliss, G.P.; Zhuang, S. Class IIa HDAC inhibitor TMP195 alleviates lipopolysaccharide-induced acute kidney injury. Am. J. Physiol. Physiol. 2020, 319, F1015-F1026. [CrossRef]

57. Yanginlar, C.; Logie, C. HDAC11 is a regulator of diverse immune functions. Biochim. Biophys. Acta 2018, 1861, 54-59. [CrossRef]

58. Janczura, K.J.; Volmar, C.H.; Sartor, G.C.; Rao, S.J.; Ricciardi, N.R.; Lambert, G.; Brothers, S.P.; Wahlestedt, C. Inhibition of HDAC3 reverses Alzheimer's disease-related pathologies in vitro and in the 3xTg-AD mouse model. Proc. Natl. Acad. Sci. USA 2018, 115, E11148-E11157. [CrossRef]

59. Leus, N.G.; van der Wouden, P.E.; van den Bosch, T.; Hooghiemstra, W.T.; Ourailidou, M.E.; Kistemaker, L.E.; Bischoff, R.; Gosens, R.; Haisma, H.J.; Dekker, F.J. HDAC 3-selective inhibitor RGFP966 demonstrates anti-inflammatory properties in RAW 264.7 macrophages and mouse precision-cut lung slices by attenuating NF- $\mathrm{B}$ p 65 transcriptional activity. Biochem. Pharmacol. 2016, 108, 58-74. [CrossRef]

60. Zhang, L.; Chen, Y.; Jiang, Q.; Song, W.; Zhang, L. Therapeutic potential of selective histone deacetylase 3 inhibition. Eur. J. Med. Chem. 2019, 162, 534-542. [CrossRef]

61. Cao, F.; Zwinderman, M.R.; Dekker, F.J. The Process and Strategy for Developing Selective Histone Deacetylase 3 Inhibitors. Molecules 2018, 23, 551. [CrossRef]

62. Huang, W.-J.; Wang, Y.-C.; Chao, S.-W.; Yang, C.-Y.; Chen, L.-C.; Lin, M.-H.; Hou, W.-C.; Chen, M.-Y.; Lee, T.-L.; Yang, P.; et al. Synthesis and biological evaluation of ortho-aryl N-hydroxycinnamides as potent histone deacetylase (HDAC) 8 isoform-selective inhibitors. ChemMedChem 2012, 7, 1815-1824. [CrossRef]

63. Jan, J.-S.; Chou, Y.-C.; Cheng, Y.-W.; Chen, C.-K.; Huang, W.-J.; Hsiao, G. The Novel HDAC8 Inhibitor WK2-16 Attenuates Lipopolysaccharide-Activated Matrix Metalloproteinase-9 Expression in Human Monocytic Cells and Improves Hypercytokinemia in vivo. Int. J. Mol. Sci. 2017, 18, 1394. [CrossRef]

64. Ran, J.; Zhou, J. Targeted inhibition of histone deacetylase 6 in inflammatory diseases. Thorac. Cancer 2019, 10, 405-412. [CrossRef]

65. Kutil, Z.; Mikešová, J.; Zessin, M.; Meleshin, M.; Nováková, Z.; Alquicer, G.; Kozikowski, A.; Sippl, W.; Bařinka, C.; Schutkowski, M. Continuous Activity Assay for HDAC11 Enabling Reevaluation of HDAC Inhibitors. ACS Omega 2019, 4, 19895-19904. [CrossRef]

66. Solomon, J.M.; Pasupuleti, R.; Xu, L.; McDonagh, T.; Curtis, R.; DiStefano, P.S.; Huber, L.J. Inhibition of SIRT1 Catalytic Activity Increases p53 Acetylation but Does Not Alter Cell Survival following DNA Damage. Mol. Cell. Biol. 2006, 26, 28-38. [CrossRef]

67. Chen, X.; Wales, P.; Quinti, L.; Zuo, F.; Moniot, S.; Hérisson, F.; Rauf, N.A.; Wang, H.; Silverman, R.B.; Ayata, C.; et al. The Sirtuin-2 Inhibitor AK7 Is Neuroprotective in Models of Parkinson's Disease but Not Amyotrophic Lateral Sclerosis and Cerebral Ischemia. PLoS ONE 2015, 10, e0116919. [CrossRef] [PubMed]

68. Gillespie, J.; Savic, S.; Wong, C.; Hempshall, A.; Inman, M.; Emery, P.; Grigg, R.; McDermott, M.F. Histone deacetylases are dysregulated in rheumatoid arthritis and a novel histone deacetylase 3-selective inhibitor reduces interleukin-6 production by peripheral blood mononuclear cells from rheumatoid arthritis patients. Arthritis Rheum. 2012, 64, 418-422. [CrossRef] [PubMed]

69. Lei, L.; Bai, G.; Wang, X.; Liu, S.; Xia, J.; Wu, S.; Huan, Y.; Shen, Z. Histone deacetylase 3-selective inhibitor RGFP966 ameliorates impaired glucose tolerance through $\beta$-cell protection. Toxicol. Appl. Pharm. 2020, 406, 115189. [CrossRef] [PubMed]

70. Zhang, H.; Ji, L.; Yang, Y.; Wei, Y.; Zhang, X.; Gang, Y.; Lu, J.; Bai, L. The Therapeutic Effects of Treadmill Exercise on Osteoarthritis in Rats by Inhibiting the HDAC3/NF-KappaB Pathway in vivo and in vitro. Front. Physiol. 2019, 10, 1060. [CrossRef] [PubMed]

71. Zhang, W.; Sun, X.; Ba, G.; Tang, R.; Lin, H. RGFP966, a selective HDAC3 inhibitor, ameliorates allergic and inflammatory responses in an OVA-induced allergic rhinitis mouse model. Int. Immunopharmacol. 2021, 93, 107400. [CrossRef]

72. Zhang, J.; Xu, Z.; Gu, J.; Jiang, S.; Liu, Q.; Zheng, Y.; Freedman, J.H.; Sun, J.; Cai, L. HDAC3 inhibition in diabetic mice may activate Nrf2 preventing diabetes-induced liver damage and FGF21 synthesis and secretion leading to aortic protection. Am. J. Physiol. Metab. 2018, 315, E150-E162. [CrossRef]

73. Zhang, M.-J.; Zhao, Q.-C.; Xia, M.-X.; Chen, J.; Chen, Y.-T.; Cao, X.; Liu, Y.; Yuan, Z.-Q.; Wang, X.-Y.; Xu, Y. The HDAC3 inhibitor RGFP966 ameliorated ischemic brain damage by downregulating the AIM2 inflammasome. FASEB J. 2019, 34, 648-662. [CrossRef]

74. Xu, Z.; Tong, Q.; Zhang, Z.; Wang, S.; Zheng, Y.; Liu, Q.; Qian, L.-B.; Chen, S.-Y.; Sun, J.; Cai, L. Inhibition of HDAC3 prevents diabetic cardiomyopathy in OVE26 mice via epigenetic regulation of DUSP5-ERK1/2 pathway. Clin. Sci. 2017, 131, 1841-1857. [CrossRef] 
75. Angiolilli, C.; Kabala, P.A.; Grabiec, A.M.; van Baarsen, I.M.; Ferguson, B.S.; García, S.; Fernandez, B.M.; McKinsey, T.A.; Tak, P.P.; Fossati, G.; et al. Histone deacetylase 3 regulates the inflammatory gene expression programme of rheumatoid arthritis fibroblast-like synoviocytes. Ann. Rheum. Dis. 2017, 76, 277-285. [CrossRef]

76. Kozikowski, A.P.; Tapadar, S.; Luchini, D.N.; Kim, K.H.; Billadeau, D.D. Use of the Nitrile Oxide Cycloaddition (NOC) Reaction for Molecular Probe Generation: A New Class of Enzyme Selective Histone Deacetylase Inhibitors (HDACIs) Showing Picomolar Activity at HDAC6. J. Med. Chem. 2008, 51, 4370-4373. [CrossRef]

77. Santo, L.; Hideshima, T.; Kung, A.L.; Tseng, J.-C.; Tamang, D.; Yang, M.; Jarpe, M.; van Duzer, J.H.; Mazitschek, R.; Ogier, W.C.; et al. Preclinical activity, pharmacodynamic, and pharmacokinetic properties of a selective HDAC6 inhibitor, ACY-1215, in combination with bortezomib in multiple myeloma. Blood 2012, 119, 2579-2589. [CrossRef]

78. Choi, E.W.; Song, J.W.; Ha, N.; Choi, Y.I.; Kim, S. CKD-506, a novel HDAC6-selective inhibitor, improves renal outcomes and survival in a mouse model of systemic lupus erythematosus. Sci. Rep. 2018, 8, 17297. [CrossRef]

79. Butler, K.V.; Kalin, J.; Brochier, C.; Vistoli, G.; Langley, B.; Kozikowski, A.P. Rational Design and Simple Chemistry Yield a Superior, Neuroprotective HDAC6 Inhibitor, Tubastatin, A. J. Am. Chem. Soc. 2010, 132, 10842-10846. [CrossRef]

80. Jochems, J.; Boulden, J.; Lee, B.G.; Blendy, J.A.; Jarpe, M.; Mazitschek, R.; van Duzer, J.H.; Jones, S.; Berton, O. Antidepressant-Like Properties of Novel HDAC6-Selective Inhibitors with Improved Brain Bioavailability. Neuropsychopharmacology 2014, 39, 389-400. [CrossRef]

81. Lee, J.W.; Lee, S.-M.; Chun, J.; Im, J.P.; Seo, S.-K.; Ha, N.; Choi, Y.I.; Kim, J.S. Novel Histone Deacetylase 6 Inhibitor CKD-506 Inhibits NF- $\mathrm{B}$ Signaling in Intestinal Epithelial Cells and Macrophages and Ameliorates Acute and Chronic Murine Colitis. Inflamm. Bowel Dis. 2020, 26, 852-862. [CrossRef] [PubMed]

82. Liu, T.; Wang, R.; Xu, H.; Song, Y.; Qi, Y. A Highly Potent and Selective Histone Deacetylase 6 Inhibitor Prevents DSS-Induced Colitis in Mice. Biol. Pharm. Bull. 2017, 40, 936-940. [CrossRef] [PubMed]

83. Do, A.; Reid, R.C.; Lohman, R.-J.; Sweet, M.J.; Fairlie, D.P.; Iyer, A. An HDAC6 Inhibitor Confers Protection and Selectively Inhibits B-Cell Infiltration in DSS-Induced Colitis in Mice. J. Pharm. Exp. 2017, 360, 140-151. [CrossRef] [PubMed]

84. Park, J.K.; Jang, Y.J.; Oh, B.R.; Shin, J.; Bae, D.; Ha, N.; Choi, Y.I.; Youn, G.S.; Park, J.; Lee, E.Y.; et al. Therapeutic potential of CKD-506, a novel selective histone deacetylase 6 inhibitor, in a murine model of rheumatoid arthritis. Arthritis Res. 2020, 22, 1-9. [CrossRef] [PubMed]

85. Vishwakarma, S.; Iyer, L.R.; Muley, M.; Singh, P.K.; Shastry, A.; Saxena, A.; Kulathingal, J.; Vijaykanth, G.; Raghul, J.; Rajesh, N.; et al. Tubastatin, a selective histone deacetylase 6 inhibitor shows anti-inflammatory and anti-rheumatic effects. Int. Immunopharmacol. 2013, 16, 72-78. [CrossRef] [PubMed]

86. Ren, J.; Panther, E.; Liao, X.; Grammer, A.C.; Lipsky, P.E.; Reilly, C.M. The Impact of Protein Acetylation/Deacetylation on Systemic Lupus Erythematosus. Int. J. Mol. Sci. 2018, 19, 4007. [CrossRef] [PubMed]

87. Lopresti, P. The Selective HDAC6 Inhibitor ACY-738 Impacts Memory and Disease Regulation in an Animal Model of Multiple Sclerosis. Front. Neurol. 2019, 10. [CrossRef]

88. Ren, Y.; Su, X.; Kong, L.; Li, M.; Zhao, X.; Yu, N.; Kang, J. Therapeutic effects of histone deacetylase inhibitors in a murine asthma model. Inflamm. Res. 2016, 65, 995-1008. [CrossRef]

89. Liu, L.; Zhou, X.; Shetty, S.; Hou, G.; Wang, Q.; Fu, J. HDAC6 inhibition blocks inflammatory signaling and caspase-1 activation in LPS-induced acute lung injury. Toxicol. Appl. Pharm. 2019, 370, 178-183. [CrossRef]

90. Ellis, J.D.; Neil, D.A.; Inston, N.G.; Jenkinson, E.; Drayson, M.T.; Hampson, P.; Shuttleworth, S.J.; Ready, A.R.; Cobbold, M. Inhibition of Histone Deacetylase 6 Reveals a Potent Immunosuppressant Effect in Models of Transplantation. Transplantation 2016, 100, 1667-1674. [CrossRef]

91. Tsuji, G.; Okiyama, N.; Villarroel, V.A.; Katz, S.I. Histone deacetylase 6 inhibition impairs effector CD8 T-cell functions during skin inflammation. J. Allergy Clin. Immunol. 2015, 135, 1228-1239. [CrossRef]

92. Li, Y.; Zhao, T.; Liu, B.; Halaweish, I.; Mazitschek, R.; Duan, X.; Alam, H.B. Inhibition of histone deacetylase 6 improves long-term survival in a lethal septic model. J. Trauma Acute Care Surg. 2015, 78, 378-385. [CrossRef]

93. Zhang, W.-B.; Zhang, H.-Y.; Jiao, F.-Z.; Wang, L.-W.; Zhang, H.; Gong, Z.-J. Histone deacetylase 6 inhibitor ACY-1215 protects against experimental acute liver failure by regulating the TLR4-MAPK/NF-кB pathway. Biomed. Pharmacother. 2018, 97, 818-824. [CrossRef]

94. Regna, N.L.; Vieson, M.D.; Luo, X.M.; Chafin, C.B.; Puthiyaveetil, A.G.; Hammond, S.E.; Caudell, D.L.; Jarpe, M.B.; Reilly, C.M. Specific HDAC6 inhibition by ACY-738 reduces SLE pathogenesis in NZB/W mice. Clin. Immunol. 2016, 162, 58-73. [CrossRef]

95. Zhou, W.; Yang, J.; Saren, G.; Zhao, H.; Cao, K.; Fu, S.; Pan, X.; Zhang, H.; Wang, A.; Chen, X. HDAC6-specific inhibitor suppresses Th17 cell function via the HIF-1 $\alpha$ pathway in acute lung allograft rejection in mice. Theranostics 2020, 10, 6790-6805. [CrossRef]

96. Lee, J.; Hong, E.C.; Jeong, H.; Hwang, J.W.; Kim, H.; Bae, E.-K.; Ahn, J.K.; Choi, Y.-L.; Han, J.; Cha, H.-S.; et al. A novel histone deacetylase 6-selective inhibitor suppresses synovial inflammation and joint destruction in a collagen antibody-induced arthritis mouse model. Int. J. Rheum. Dis. 2015, 18, 514-523. [CrossRef]

97. Yee, A.J.; Bensinger, W.I.; Supko, J.G.; Voorhees, P.M.; Berdeja, J.G.; Richardson, P.G.; Libby, E.N.; Wallace, E.E.; Birrer, E.N.; Burke, J.N.; et al. Ricolinostat plus lenalidomide, and dexamethasone in relapsed or refractory multiple myeloma: A multicentre phase 1b trial. Lancet Oncol. 2016, 17, 1569-1578. [CrossRef] 
98. Vogl, D.T.; Raje, N.; Jagannath, S.; Richardson, P.; Hari, P.; Orlowski, R.; Supko, J.G.; Tamang, D.; Yang, M.; Jones, S.S.; et al. Ricolinostat, the First Selective Histone Deacetylase 6 Inhibitor, in Combination with Bortezomib and Dexamethasone for Relapsed or Refractory Multiple Myeloma. Clin. Cancer Res. 2017, 23, 3307-3315. [CrossRef]

99. Shultz, M.D.; Cao, X.; Chen, C.H.; Cho, Y.S.; Davis, N.R.; Eckman, J.; Fan, J.; Fekete, A.; Firestone, B.; Flynn, J.; et al. Optimization of the in Vitro Cardiac Safety of Hydroxamate-Based Histone Deacetylase Inhibitors. J. Med. Chem. 2011, 54, 4752-4772. [CrossRef]

100. Kopljar, I.; Gallacher, D.J.; De Bondt, A.; Cougnaud, L.; Vlaminckx, E.; Wyngaert, I.V.D.; Lu, H.R. Functional and Transcriptional Characterization of Histone Deacetylase Inhibitor-Mediated Cardiac Adverse Effects in Human Induced Pluripotent Stem Cell-Derived Cardiomyocytes. Stem Cells Transl. Med. 2016, 5, 602-612. [CrossRef]

101. Li, P.; Ninomiya, H.; Kurata, Y.; Kato, M.; Miake, J.; Yamamoto, Y.; Igawa, O.; Nakai, A.; Higaki, K.; Toyoda, F.; et al. Reciprocal Control of hERG Stability by Hsp70 and Hsc70 With Implication for Restoration of LQT2 Mutant Stability. Circ. Res. 2011, 108, 458-468. [CrossRef] [PubMed]

102. Lin, F.-L.; Yen, J.-L.; Kuo, Y.-C.; Kang, J.-J.; Cheng, Y.-W.; Huang, W.-J.; Hsiao, G. HADC8 Inhibitor WK2-16 Therapeutically Targets Lipopolysaccharide-Induced Mouse Model of Neuroinflammation and Microglial Activation. Int. J. Mol. Sci. 2019, 20, 410. [CrossRef] [PubMed]

103. Balasubramanian, S.; Ramos, J.; Luo, W.; Sirisawad, M.; Verner, E.; Buggy, J.J. A novel histone deacetylase 8 (HDAC8)-specific inhibitor PCI-34051 induces apoptosis in T-cell lymphomas. Leukemia 2008, 22, 1026-1034. [CrossRef] [PubMed]

104. Zuberi, R.I.; Hsu, D.K.; Kalayci, O.; Chen, H.-Y.; Sheldon, H.K.; Yu, L.; Apgar, J.R.; Kawakami, T.; Lilly, C.M.; Liu, F.-T. Critical Role for Galectin-3 in Airway Inflammation and Bronchial Hyperresponsiveness in a Murine Model of Asthma. Am. J. Pathol. 2004, 165, 2045-2053. [CrossRef]

105. Pavlik, C.M.; Wong, C.Y.B.; Ononye, S.; Lopez, D.D.; Engene, N.; McPhail, K.L.; Gerwick, W.H.; Balunas, M.J. Santacruzamate A, a Potent and Selective Histone Deacetylase Inhibitor from the Panamanian Marine Cyanobacterium cf. Symploca sp. J. Nat. Prod. 2013, 76, 2026-2033. [CrossRef]

106. Jiao, F.-Z.; Wang, Y.; Zhang, H.-Y.; Zhang, W.-B.; Wang, L.-W.; Gong, Z.-J. Histone Deacetylase 2 Inhibitor CAY10683 Alleviates Lipopolysaccharide Induced Neuroinflammation through Attenuating TLR4/NF-кB Signaling Pathway. Neurochem. Res. 2018, 43, 1161-1170. [CrossRef]

107. Poralla, L.; Stroh, T.; Erben, U.; Sittig, M.; Liebig, S.; Siegmund, B.; Glauben, R. Histone deacetylase 5 regulates the inflammatory response of macrophages. J. Cell. Mol. Med. 2015, 19, 2162-2171. [CrossRef]

108. Liao, W.; Sun, J.; Liu, W.; Li, W.; Jia, J.; Ou, F.; Su, K.; Zheng, Y.; Zhang, Z.; Sun, Y. HDAC10 upregulation contributes to interleukin $1 \beta$-mediated inflammatory activation of synovium-derived mesenchymal stem cells in temporomandibular joint. J. Cell. Physiol. 2019, 234, 12646-12662. [CrossRef]

109. Son, S.I.; Cao, J.; Zhu, C.-L.; Miller, S.P.; Lin, H. Activity-Guided Design of HDAC11-Specific Inhibitors. ACS Chem. Biol. 2019, 14, 1393-1397. [CrossRef]

110. Oishi, Y.; Manabe, I. Macrophages in inflammation, repair and regeneration. Int. Immunol. 2018, 30, 511-528. [CrossRef]

111. Koh, T.J.; DiPietro, L.A. Inflammation and wound healing: The role of the macrophage. Expert Rev. Mol. Med. 2011, 13, e23. [CrossRef]

112. Lian, J.; Nelson, R.; Lehner, R. Carboxylesterases in lipid metabolism: From mouse to human. Protein Cell 2018, 9, 178-195. [CrossRef]

113. Satoh, T.; Hemmerlein, B.; Zschunke, F.; Radzun, H.J. In situ Detection of Human Monocyte/Macrophage Serine Esterase-1 mRNA Expression in Human Tissues. Pathobiology 1999, 67, 158-162. [CrossRef]

114. Imai, T. Human Carboxylesterase Isozymes: Catalytic Properties and Rational Drug Design. Drug Metab. Pharm. 2006, 21, 173-185. [CrossRef]

115. Ossenkoppele, G.J.; Lowenberg, B.; Zachee, P.; Vey, N.; Breems, D.; van de Loosdrecht, A.A.; Davidson, A.H.; Wells, G.; Needham, L.; Bawden, L.; et al. A phase I first-in-human study with tefinostat-a monocyte/macrophage targeted histone deacetylase inhibitor-in patients with advanced haematological malignancies. Br. J. Haematol. 2013, 162, 191-201. [CrossRef]

116. Elfiky, A.; Ghiboub, M.; van Hamersveld, H.P.; Welting, O.; van den Berg, I.; Rahman, S.; de Winther, M.; Becker, M.; Wildenberg, M.E.; Furze, R.; et al. Mo1104 Mononuclear Myeloid Cell Targeted Histone Deactylase (HDAC) Inhibitor Demonstrates Potent Activity in Monocytes and Impairs Colon Monocytes to Macrophage Differentation During Acute DSS Colitis. Gastroenterology 2020, 158, 789-790. [CrossRef]

117. Luque-Martin, R.; van den Bossche, J.; Furze, R.C.; Neele, A.E.; van der Velden, S.; Gijbels, M.J.J.; van Roomen, C.P.P.A.; Bernard, S.G.; de Jonge, W.J.; Rioja, I.; et al. Targeting Histone Deacetylases in Myeloid Cells Inhibits Their Maturation and Inflammatory Function with Limited Effects on Atherosclerosis. Front. Pharm. 2019, 10, 1242. [CrossRef]

118. Fan, X.; Zhang, H.; Cheng, Y.; Jiang, X.; Zhu, J.; Jin, T. Double Roles of Macrophages in Human Neuroimmune Diseases and Their Animal Models. Mediat. Inflamm. 2016, 2016, 1-13. [CrossRef]

119. Liu, Y.-C.; Zou, X.-B.; Chai, Y.-F.; Yao, Y.-M. Macrophage Polarization in Inflammatory Diseases. Int. J. Biol. Sci. 2014, 10, 520-529. [CrossRef]

120. Fujisawa, T.; Filippakopoulos, P. Functions of bromodomain-containing proteins and their roles in homeostasis and cancer. Nat. Rev. Mol. Cell Biol. 2017, 18, 246-262. [CrossRef]

121. Meslamani, J.; Smith, S.G.; Sanchez, R.; Zhou, M.-M. Structural features and inhibitors of bromodomains. Drug Discov. Today Technol. 2016, 19, 3-15. [CrossRef] [PubMed] 
122. Dawson, M.A.; Prinjha, R.K.; Dittmann, A.; Giotopoulos, G.; Bantscheff, M.; Chan, W.-I.; Robson, S.C.; Chung, C.-W.; Hopf, C.; Savitski, M.M.; et al. Inhibition of BET recruitment to chromatin as an effective treatment for MLL-fusion leukaemia. Nat. Cell Biol. 2011, 478, 529-533. [CrossRef]

123. Cochran, A.G.; Conery, A.R.; Sims, R.J. Bromodomains: A new target class for drug development. Nat. Rev. Drug Discov. 2019, 18, 609-628. [CrossRef] [PubMed]

124. Guo, D.; Hong, D.; Wang, P.; Wang, J.; Chen, L.; Zhao, W.; Zhang, L.; Yao, C.; Chu, B.; Chen, S.; et al. Histone deacetylase inhibitor CI-994 inhibits osteoclastogenesis via suppressing NF-KB and the downstream c-Fos/NFATc1 signaling pathways. Eur. J. Pharmacol. 2019, 848, 96-104. [CrossRef]

125. Malvaez, M.; McQuown, S.C.; Rogge, G.A.; Astarabadi, M.; Jacques, V.; Carreiro, S.; Rusche, J.R.; Wood, M.A. HDAC3-selective inhibitor enhances extinction of cocaine-seeking behavior in a persistent manner. Proc. Natl. Acad. Sci. USA 2013, 110, $2647-2652$. [CrossRef]

126. Liu, Z.; Tian, B.; Chen, H.; Wang, P.; Brasier, A.R.; Zhou, J. Discovery of potent and selective BRD4 inhibitors capable of blocking TLR3-induced acute airway inflammation. Eur. J. Med. Chem. 2018, 151, 450-461. [CrossRef]

127. Tian, B.; Liu, Z.; Litvinov, J.; Maroto, R.; Jamaluddin, M.; Rytting, E.; Patrikeev, I.; Ochoa, L.; Vargas, G.; Motamedi, M.; et al. Efficacy of Novel Highly Specific Bromodomain-Containing Protein 4 Inhibitors in Innate Inflammation-Driven Airway Remodeling. Am. J. Respir. Cell Mol. Biol. 2019, 60, 68-83. [CrossRef]

128. Theodoulou, N.H.; Bamborough, P.; Bannister, A.J.; Becher, I.; Bit, R.A.; Che, K.H.; Chung, C.-W.; Dittmann, A.; Drewes, G.; Drewry, D.H.; et al. Discovery of I-BRD9, a Selective Cell Active Chemical Probe for Bromodomain Containing Protein 9 Inhibition. J. Med. Chem. 2016, 59, 1425-1439. [CrossRef]

129. Martin, L.J.; Koegl, M.; Bader, G.; Cockcroft, X.-L.; Fedorov, O.; Fiegen, D.; Gerstberger, T.; Hofmann, M.H.; Hohmann, A.F.; Kessler, D.; et al. Structure-Based Design of an in vivo Active Selective BRD9 Inhibitor. J. Med. Chem. 2016, 59, $4462-4475$. [CrossRef]

130. Lv, Q.; Yang, A.; Shi, W.; Chen, F.; Liu, Y.; Liu, Y.; Wang, D. Calcipotriol and iBRD9 reduce obesity in Nur77 knockout mice by regulating the gut microbiota, improving intestinal mucosal barrier function. Int. J. Obes. 2020, 44, 1052-1061. [CrossRef]

131. Gilan, O.; Rioja, I.; Knezevic, K.; Bell, M.J.; Yeung, M.M.; Harker, N.R.; Lam, E.Y.N.; Chung, C.-W.; Bamborough, P.; Petretich, M.; et al. Selective targeting of BD1 and BD2 of the BET proteins in cancer and immunoinflammation. Science 2020, 368, 387-394. [CrossRef]

132. Taniguchi, Y. The Bromodomain and Extra-Terminal Domain (BET) Family: Functional Anatomy of BET Paralogous Proteins. Int. J. Mol. Sci. 2016, 17, 1849. [CrossRef]

133. Nicodeme, E.; Jeffrey, K.L.; Schaefer, U.; Beinke, S.; Dewell, S.; Chung, C.-W.; Chandwani, R.; Marazzi, I.; Wilson, P.; Coste, H.; et al. Suppression of inflammation by a synthetic histone mimic. Nat. Cell Biol. 2010, 468, 1119-1123. [CrossRef]

134. Filippakopoulos, P.; Qi, J.; Picaud, S.; Shen, Y.; Smith, M.C.; Fedorov, O.; Morse, E.M.; Keates, T.; Hickman, T.T.; Felletar, I.; et al. Selective inhibition of BET bromodomains. Nature 2010, 468, 1067-1073. [CrossRef]

135. Wyce, A.; Ganji, G.; Smitheman, K.N.; Chung, C.-W.; Korenchuk, S.; Bai, Y.; Barbash, O.; Le, B.; Craggs, P.D.; McCabe, M.T.; et al. BET Inhibition Silences Expression of MYCN and BCL2 and Induces Cytotoxicity in Neuroblastoma Tumor Models. PLoS ONE 2013, 8, e72967. [CrossRef]

136. Chan, C.H.; Fang, C.; Qiao, Y.; Yarilina, A.; Prinjha, R.K.; Ivashkiv, L.B. BET bromodomain inhibition suppresses transcriptional responses to cytokine-Jak-STAT signaling in a gene-specific manner in human monocytes. Eur. J. Immunol. 2015, 45, 287-297. [CrossRef]

137. Miller, T.C.R.; Simon, B.; Rybin, V.; Grötsch, H.; Curtet, S.; Khochbin, S.; Carlomagno, T.; Müller, C.W. A bromodomain-DNA interaction facilitates acetylation-dependent bivalent nucleosome recognition by the BET protein BRDT. Nat. Commun. 2016, 7, 13855. [CrossRef]

138. Baud, M.G.J.; Lin-Shiao, E.; Cardote, T.; Tallant, C.; Pschibul, A.; Chan, K.-H.; Zengerle, M.; Garcia, J.R.; Kwan, T.T.-L.; Ferguson, F.M.; et al. A bump-and-hole approach to engineer controlled selectivity of BET bromodomain chemical probes. Science 2014, 346, 638-641. [CrossRef]

139. Shi, J.; Wang, E.; Milazzo, J.P.; Wang, Z.; Kinney, J.B.; Vakoc, C.R. Discovery of cancer drug targets by CRISPR-Cas9 screening of protein domains. Nat. Biotechnol. 2015, 33, 661-667. [CrossRef]

140. Faivre, E.J.; McDaniel, K.F.; Albert, D.H.; Mantena, S.R.; Plotnik, J.P.; Wilcox, D.; Zhang, L.; Bui, M.H.; Sheppard, G.S.; Wang, L.; et al. Selective inhibition of the BD2 bromodomain of BET proteins in prostate cancer. Nat. Cell Biol. 2020, 578, 306-310. [CrossRef]

141. Filippakopoulos, P.; Knapp, S. Next-generation epigenetic inhibitors. Science 2020, 368, 367-368. [CrossRef] [PubMed]

142. Zhang, G.; Plotnikov, A.N.; Rusinova, E.; Shen, T.; Morohashi, K.; Joshua, J.; Zeng, L.; Mujtaba, S.; Ohlmeyer, M.; Zhou, M.-M. Structure-Guided Design of Potent Diazobenzene Inhibitors for the BET Bromodomains. J. Med. Chem. 2013, 56, 9251-9264. [CrossRef] [PubMed]

143. Nowak, R.P.; DeAngelo, S.L.; Buckley, D.; He, Z.; Donovan, K.A.; An, J.; Safaee, N.; Jedrychowski, M.P.; Ponthier, C.M.; Ishoey, M.; et al. Plasticity in binding confers selectivity in ligand-induced protein degradation. Nat. Chem. Biol. 2018, 14, 706-714. [CrossRef] [PubMed] 
144. Qin, C.; Hu, Y.; Zhou, B.; Fernandez-Salas, E.; Yang, C.-Y.; Liu, L.; McEachern, D.; Przybranowski, S.; Wang, M.; Stuckey, J.; et al. Discovery of QCA570 as an Exceptionally Potent and Efficacious Proteolysis Targeting Chimera (PROTAC) Degrader of the Bromodomain and Extra-Terminal (BET) Proteins Capable of Inducing Complete and Durable Tumor Regression. J. Med. Chem. 2018, 61, 6685-6704. [CrossRef]

145. Yim, A.Y.F.L.; Duijvis, N.W.; Zhao, J.; de Jonge, W.J.; D’Haens, G.R.A.M.; Mannens, M.M.A.M.; Mul, A.N.P.M.; Velde, A.A.T.; Henneman, P. Peripheral blood methylation profiling of female Crohn's disease patients. Clin. Epigenet. 2016, 8, 1-13. [CrossRef]

146. Franke, A.; McGovern, D.P.B.; Barrett, J.C.; Wang, K.; Radford-Smith, G.L.; Ahmad, T.; Lees, C.W.; Balschun, T.; Lee, J.; Roberts, R.; et al. Genome-wide meta-analysis increases to 71 the number of confirmed Crohn's disease susceptibility loci. Nat. Genet. 2010, 42, 1118-1125. [CrossRef]

147. Sima, X.; He, J.; Peng, J.; Xu, Y.; Zhang, F.; Deng, L. The genetic alteration spectrum of the SWI/SNF complex: The oncogenic roles of BRD9 and ACTL6A. PLoS ONE 2019, 14, e0222305. [CrossRef]

148. Loo, C.-S.; Gatchalian, J.; Liang, Y.; Leblanc, M.; Xie, M.; Ho, J.; Venkatraghavan, B.; Hargreaves, D.C.; Zheng, Y. A Genome-wide CRISPR Screen Reveals a Role for the Non-canonical Nucleosome-Remodeling BAF Complex in Foxp3 Expression and Regulatory T Cell Function. Immunity 2020, 53, 143-157. [CrossRef]

149. Wen, A.Y.; Sakamoto, K.M.; Miller, L.S. The Role of the Transcription Factor CREB in Immune Function. J. Immunol. 2010, 185, 6413-6419. [CrossRef]

150. Zhang, S.; Xu, W.; Wang, H.; Cao, M.; Li, M.; Zhao, J.; Hu, Y.; Wang, Y.; Li, S.; Xie, Y.; et al. Inhibition of CREB-mediated ZO-1 and activation of NF-kB-induced IL-6 by colonic epithelial MCT4 destroys intestinal barrier function. Cell Prolif. 2019, 52 , e12673. [CrossRef]

151. Takeba, Y.; Suzuki, N.; Wakisaka, S.; Takeno, M.; Kaneko, A.; Asai, T.; Sakane, T. Involvement of cAMP responsive element binding protein (CREB) in the synovial cell hyperfunction in patients with rheumatoid arthritis. Clin. Exp. Rheumatol. 2000, $18,47-55$.

152. Chekler, E.L.P.; Pellegrino, J.A.; Lanz, T.A.; Denny, R.A.; Flick, A.C.; Coe, J.; Langille, J.; Basak, A.; Liu, S.; Stock, I.A.; et al. Transcriptional Profiling of a Selective CREB Binding Protein Bromodomain Inhibitor Highlights Therapeutic Opportunities. Chem. Biol. 2015, 22, 1588-1596. [CrossRef]

153. Best, J.L.; Amezcua, C.A.; Mayr, B.; Flechner, L.; Murawsky, C.M.; Emerson, B.; Zor, T.; Gardner, K.H.; Montminy, M. Identification of small-molecule antagonists that inhibit an activator: Coactivator interaction. Proc. Natl. Acad. Sci. USA 2004, 101, 17622-17627. [CrossRef]

154. Igoe, N.; Bayle, E.D.; Tallant, C.; Fedorov, O.; Meier, J.C.; Savitsky, P.; Rogers, C.; Morias, Y.; Scholze, S.; Boyd, H.; et al. Design of a Chemical Probe for the Bromodomain and Plant Homeodomain Finger-Containing (BRPF) Family of Proteins. J. Med. Chem. 2017, 60, 6998-7011. [CrossRef]

155. Meier, J.C.; Tallant, C.; Fedorov, O.; Witwicka, H.; Hwang, S.-Y.; Van Stiphout, R.G.; Lambert, J.-P.; Rogers, C.; Yapp, C.; Gerstenberger, B.S.; et al. Selective Targeting of Bromodomains of the Bromodomain-PHD Fingers Family Impairs Osteoclast Differentiation. ACS Chem. Biol. 2017, 12, 2619-2630. [CrossRef] [PubMed]

156. Brown, J.A.; Jones, K.L.; Prinjha, R.K.; Witherington, J. Covalent conjugates of bet inhibitors and alpha amino acid esters. U.S. Patent 15/559,518, 22 September 2016.

157. Felice, C.; Lewis, A.; Armuzzi, A.; Lindsay, J.O.; Silver, A. Review article: Selective histone deacetylase isoforms as potential therapeutic targets in inflammatory bowel diseases. Aliment. Pharm. 2014, 41, 26-38. [CrossRef] 